\title{
Nematobacterial Complexes and Insect Hosts: Different Weapons for the Same War
}

\author{
Maurizio Francesco Brivio * ${ }^{(D)}$ and Maristella Mastore \\ Laboratory of Comparative Immunology and Parasitology, Department of Theoretical and Applied Sciences, \\ University of Insubria, 21100 Varese, Italy; maristella.mastore@uninsubria.it \\ * Correspondence: maurizio.brivio@uninsubria.it; Tel.: +39-0332-421-404
}

Received: 20 July 2018; Accepted: 6 September 2018; Published: 11 September 2018

\begin{abstract}
Entomopathogenic nematodes (EPNs) are widely used as biological control agents against insect pests, the efficacy of these organisms strongly depends on the balance between the parasitic strategies and the immune response of the host. This review summarizes roles and relationships between insect hosts and two well-known EPN species, Steinernema feltiae and Steinernema carpocapsae and outlines the main mechanisms of immune recognition and defense of insects. Analyzing information and findings about these EPNs, it is clear that these two species use shared immunosuppression strategies, mainly mediated by their symbiotic bacteria, but there are differences in both the mechanism of evasion and interference of the two nematodes with the insect host immune pathways. Based on published data, S. feltiae takes advantage of the cross reaction between its body surface and some host functional proteins, to inhibit defensive processes; otherwise, secretion/excretion products from S. carpocapsae seem to be the main nematode components responsible for the host immunosuppression.
\end{abstract}

Keywords: entomopathogenic nematodes; innate immunity; insect host; Steinernema feltiae; Steinernema carpocapsae; Xenorhabdus bovienii; Xenorhabdus nematophila; host-parasite

\section{Introduction}

Nematodes are one of the most abundant groups of animals on earth [1], and thanks to their small size, their resistant cuticle and their ability to adapt to severe environmental changes, they have colonized a wide range of habitats including vertebrates' and invertebrates' bodies, so nematodes may be free-living or parasitic [2,3]. The latter are usually considered pests because they cause important diseases in animals and humans, and due to their economic impact on many agricultural products.

A small but significant number of parasitic nematodes, called entomopathogenic nematodes (EPNs), are of considerable interest because they possess various features that could allow them to be used as biological control agents for pest insects [4-6]. EPNs must meet criteria to be considered good candidates for biological control: they should target environmental pests and insect vectors, and be able to kill, sterilize, or hamper the development of their insect targets. Insect-parasitic nematodes that possess optimal features as bio-insecticides belong to the families Steinernematidae and Heterorhabditidae (Nematoda, Rhabditidae). Steinernematidae and Heterorhabditidae are not closely related phylogenetically, but through convergent evolution, they have similar life histories [7].

The natural host range of Steinernema spp. and Heterorhabditis spp. can be defined as the range of insects which indigenous nematode populations use for their propagation. A distinction has however to be made between the range of insect species being susceptible to nematodes in the laboratory, the range of hosts successfully controlled by inundative release of nematodes (field host range) and the range of insects on which a naturally occurring nematode population propagates. The latter, 
called the natural host range, is poorly defined, thought an overview on this subject has been proposed by Peters [8].

Steinernematidae and Heterorhabditidae use different method of parasitization that can be defined as static (ambushing) or active (cruising); Steinernema spp. are usually considered as static, since they wait for host proximity, but there are many examples of mixed foraging strategies by which they combine ambushing and cruising approaches to reach the host $[9,10]$. Heterorhabditis spp. actively approach their host, even if we cannot exclude that there are species not yet described, that behave like ambush foragers.

Regarding reproductive strategies, Steinernema spp. are mostly gonochoristic but there are hermaphroditic species such as S. hermaphroditum [11], Heterorhabditis spp. are commonly considered as hermaphroditic, although, as demonstrated by Chaudhuri et al. [12] Rhabditis sp. SB347, a nematode with sexual polymorphism, produces males, females and hermaphrodites.

Most of the nematodes in these families differ from other Rhabditidae by having a species-specific mutualistic relationship with bacteria: Xenorhabdus, associated with Steinernematidae [13,14], and Photorhabdus, associated with Heterorhabditidae [15-19]. However, non-symbiotic bacteria associated with different EPNs have been described in the literature [20], these microorganisms have been found either in the gut or in other body regions [21]. The role of these bacteria has not been completely clarified, even if they sometimes show a pathogenicity towards the host and resistance to antibiotics produced by the symbionts of the nematode [22,23]. Some exceptions have been reviewed by Dillman et al. [24] who stated, about some newly described associations, that nematode-bacterium partnerships should not be considered entomopathogens if they do not explicitly fulfill the requirements to be classified as EPNs, e.g., the heritability of their bacterial associations.

The symbiotic bacteria (Figure 1) contribute to the nematodes' ability to kill the host; they establish suitable conditions for nematode reproduction, providing nutrients and inhibiting the growth of other microorganisms in the insect host, by the release of antimicrobial compounds.

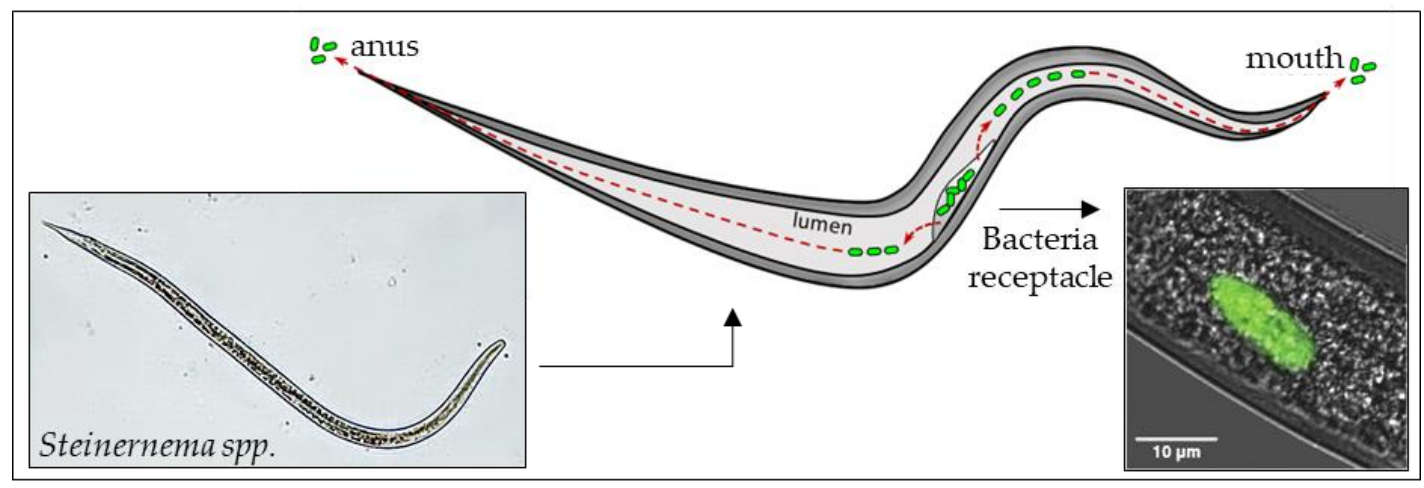

Figure 1. EPNs symbiotic bacteria (Xenorhabdus spp.) live in a monoxenic area, or in differentiated vesicles of the anterior part of intestine, modified as a bacterial receptacle. Micrograph at right shows fluorescent GFP-transformed bacteria inside Steinernema spp. intestine, (image at right, courtesy of J. Chaston, from [25]).

At the same time, the nematode acts as a vector for the symbiotic bacteria, and, by interacting early with the host immune system, it prepares a favorable environment for its symbionts. The symbiotic relationship is essential for the efficiency of the biocontrol and it enables nematodes to exploit a diverse array of insect hosts [26,27].

In general, endoparasites penetrate invertebrate hosts by overcoming the first line of defense, consisting of the exoskeleton and mucosal tissues of the external openings and once they reach the hemocoel cavity, they must elude the host's recognition system and/or depress immune effector processes [28].

It is generally accepted that, to survive, a parasite must reach an ideal equilibrium with its host; however, in the case of EPNs, the parasite must kill its host and though this could seems a disadvantage, 
because it reduces the number of hosts, it is an essential condition for EPNs, since they use the host corpse as an environment for the development of their offspring. Thus, EPNs can be considered as parasitoids whose behavior is characterized by the lethal nature of their interaction with their host. It is very important to be aware that EPNs are nematode-bacteria complexes and that the success of their parasitic interaction (Figure 2) with the infected hosts is based on the synergism between the parasite itself and its symbiotic bacteria. In addition, to gain an in depth understanding of the host-parasite relationship that is established by EPNs, it is pivotal to summarize processes and components of the insect immune system that are involved in recognition and neutralization of invaders.

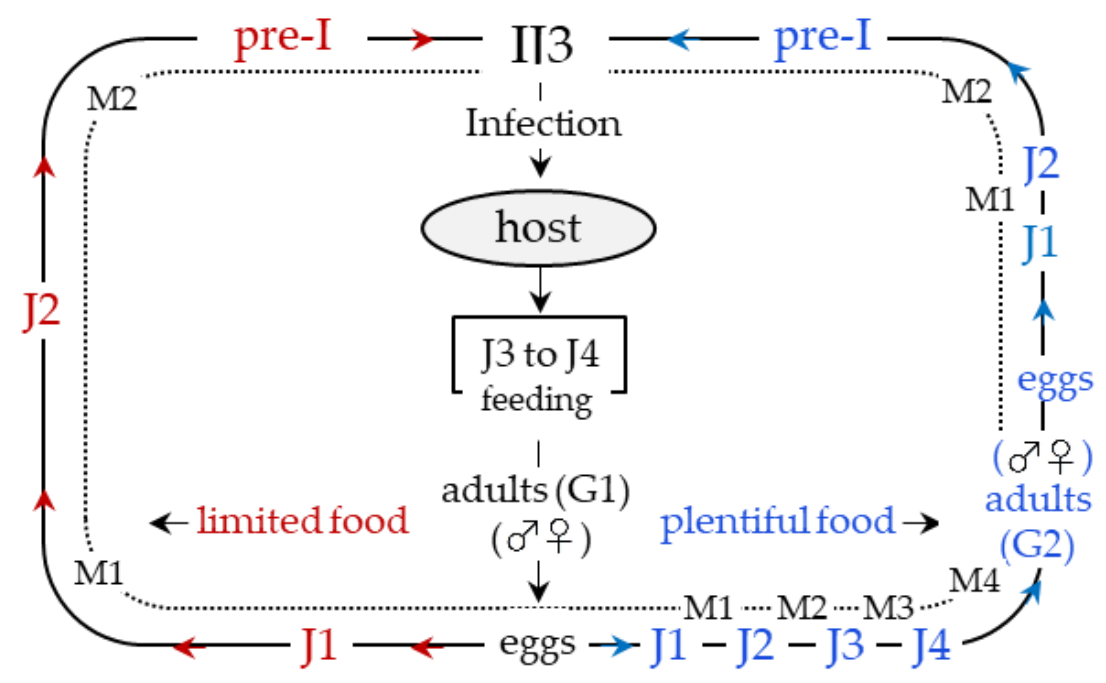

Figure 2. EPNs life cycle. After infection of the host, the infective juvenile stage (IJ3) develop to J4 and to adults (G1), and after mating the eggs develop to J1. If food is scarce, they molt in succession to J2 and pre-I (pre-infective stage juvenile), which will become infective (IJ3). Otherwise, in the presence of abundant food, nematodes molt in succession to the fourth stage (J4), and to adults (G2), and after mating eggs develop into J1, J2, pre-I and finally to IJ3. At the IJ3 stage nematodes search for new hosts to infect. M: Molt; J: Juvenile stage; G: Generation.

\section{An Overview of the Insect Immune System: Sensing and Recognition of Non-Self}

Insects possess a potent innate immune system by which they attempt to resist microbial infections and parasitic invasions [29]. However, this may not always be effective because some invaders have developed sophisticated survival mechanisms to live and complete their life cycles within the host body. Insects, and invertebrates in general, can discriminate between self and non-self by means of a powerful innate immune system $[30,31]$, and consequently, endoparasites must overcome the host immune defenses to complete their life cycles [32,33].

The innate immune system is characterized by the absence of adaptive immune recognition receptors, although pattern-recognition receptors (PRRs) are used to interact specifically with a broad range of foreign antigenic compounds, commonly named pathogen-associated molecular patterns (PAMPs). The interaction between PAMPs and PRRs is a crucial step in the discriminatory processes of innate immunity that usually precedes the effector mechanisms responsible for the elimination of non-self [34-37]. Innate immunity is common to all metazoans and serves as a first-line defense against foreign antigens. Innate immune responses are not specific to a particular antigen in the way that the adaptive immune responses are, its hallmarks are the recognition of non-self by germ line-encoded non-rearranging receptors and rapid effector mechanisms that involve several cell-mediated and humoral processes $[38,39]$.

Insect responses involve both cellular and humoral defense mechanisms, and all these processes are triggered by free and membrane-bound PRRs capable of specifically binding to PAMPs [35]. PAMPs are molecules that are common to groups of pathogens, these can be referred to as small molecular motifs 
conserved within a class of microbes, and they are recognized by free or cell-associated receptors (PRRs) in all animal species. The prototypical PAMPs (Figure 3) could be molecules secreted or derived from the surface of bacteria and fungi, or nucleic acid variants normally associated with viruses [40-47].

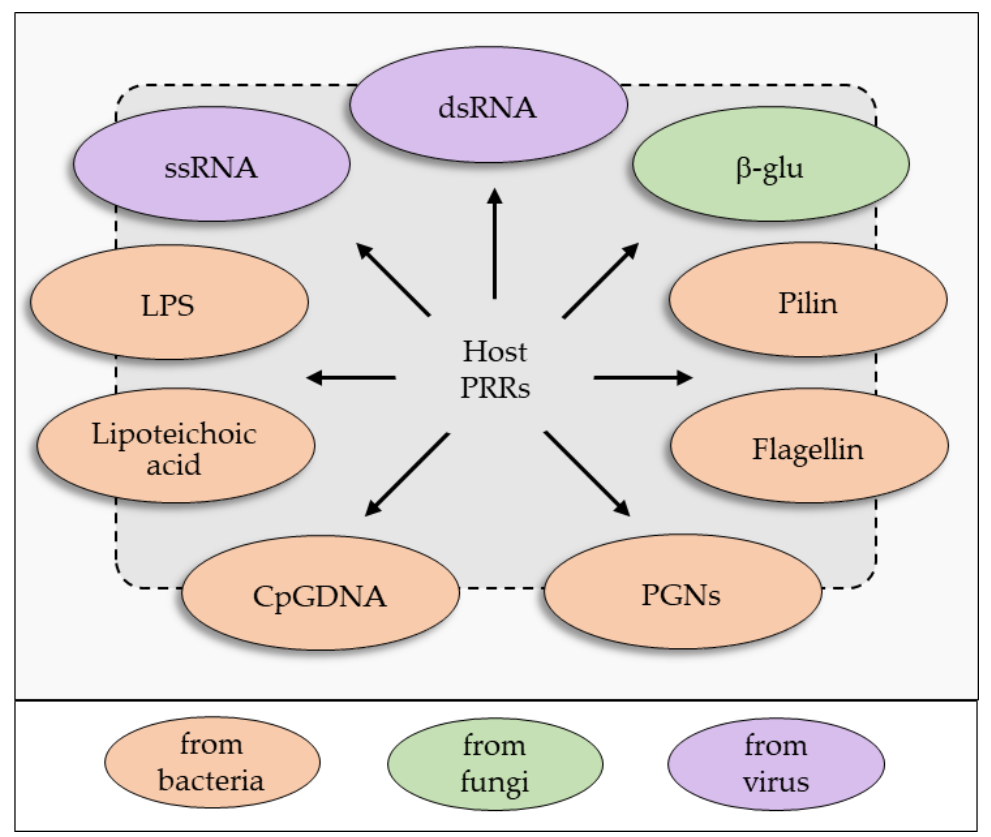

Figure 3. PAMPs from invaders are recognized by free, or cell-associated host receptors (PRRs). Typical PAMPs are: bacterial lipopolysaccharide (LPS), bacterial peptidoglycans (PGNs), $\beta$-glucans from fungi ( $\beta$-glu), lipoteichoic acid from Gram positive bacteria, bacterial flagellin and pilin, nucleic acid variants such as single or double-stranded RNA (ssRNA, dsRNA) and unmethylated CpG motifs (CpGDNA).

\subsection{Humoral Immune Recognition}

In insects, the presence of non-self (microorganisms or metazoans) can selectively stimulate several immune reactions and sometimes lead to the differential expression of effector genes, but any immune reaction is preceded by the interaction of PRRs with PAMPs and thus of the subsequent triggering of defensive reactions $[35,48,49]$.

Many proteins that act as PRRs have been identified in the hemolymph of various insect species. The roles of PRRs have been exhaustively discussed by Kanost and co-workers [36], who described peptidoglycan-receptor proteins (PGRPs), $\beta$-glucan receptors ( $\beta$-GRPs) and immuno-related oligosaccharides-receptors, known as immulectins (IMLs), in Manduca sexta (Lepidoptera). In recent years, the central role of the PGRP family has been highlighted; the sensing of peptidoglycan molecules by these receptors seems to be essential to activate different pathways of innate immunity. Glucan-binding proteins (GNBPs) specific for DAP-type and Lys-type peptidoglycans from Gram-negative and Gram-positive bacteria, respectively, [50] are involved in Toll and Imd pathways and they stimulate the synthesis of antimicrobial peptides. Further roles for soluble PGRPs have been suggested, for example they can function as opsonic factors, bactericidal factors and modulators of the prophenoloxidase activating system (proPO-AS) [51,52]. A PGRP was isolated as a $19 \mathrm{kDa}$ protein in M. sexta hemolymph, and its mRNA, found in fat bodies, seems to be either constitutive or inducible a few hours after injection of bacteria. Manduca PGRP is responsible for the activation of several immunological pathways, without enhancing the activity of host proPO-AS [53,54]. Two $\beta$-GRPs are present in the hemolymph ( $\beta$-GRP-1 and $\beta$-GRP-2) which bind $\beta-1,3$ glucans and lipoteichoic acid, thus agglutinating both Gram-negative and Gram-positive bacteria and triggering host proPO-AS [55]; the mRNAs for these proteins are constitutively present in fat body cells ( $\beta$-GRP-1 mRNA) or up-regulated following infection of bacteria or yeast ( $\beta$-GRP-2 mRNA). 
A third family of PRRs found in M. sexta belongs to the C-type lectins (calcium-dependent lectins); these proteins contain at least a 110-130 carbohydrate-recognition domain that interacts with free proteins or lipid-conjugated oligosaccharides [56,57]. Four immulectins (IMLs) were isolated and characterized in bacteria-challenged larval hemolymph, all are involved in binding of lipopolysaccharides (LPS). For example, IML-1 and IML-2, when complexed with LPS, modulate the Manduca proPO-AS [58,59].

In 1997, Dunphy and Halwani [60] isolated two LPS-binding proteins (LBPs), named LBP-1 (17.2 kDa) and LBP-2 (26 kDa), from G. mellonella naïve larvae; the authors reported that these soluble receptors are specific for the bacterial surface and seem to act as endotoxin detoxifiers, thus protecting hemocytes from damage. Both LBPs are specific for the lipid A region of LPS and LBP-1 acts as an activator of proPO-AS. Wiesner and co-workers [61] isolated and described a hemolymph protein called Apolipophorin-III (ApoLp-III), with a molecular mass of $17 \mathrm{kDa}$; ApoLp-III has been identified as an immune-stimulating factor in lepidopteran insects. The immune-stimulating capacity of ApoLp-III is surprising, since this protein is known to play an important role in lipid transport in flying insects. Injection of natively purified, as well as of recombinant ApoLp-III [62], from G. mellonella into the hemocoel of untreated larvae led to a strong increase of antibacterial activity within the hemolymph [63]; the induced antibacterial activity reached the same intensity as that which can be maximally provoked by injecting bacteria. Thus, ApoLp-III represents a further endogenous mediator which is involved in the regulation of insect immune responses [64]. Therefore, the discriminatory phase of innate immunity seems to be based on a few receptors that have the ability to recognize a large number of foreign molecular patterns.

\subsection{Cellular Immune Recognition}

In insects, hemocytes freely circulate in the hemolymph, or are localized in specific regions of the body (e.g., fat body cells). Hemocytes play a role in several defensive functions against foreign targets, and in general, they need to be activated by the presence of PAMPs and/or by endogenous soluble factors. This activation is often mediated by specific membrane receptors that are able to recognize and bind their co-receptors. Following this interaction, hemocytes become stimulated and initiate complex mechanisms such as intracellular signal transduction that culminates in the activation of specific immune genes [65], or initiates defense mechanisms such as phagocytosis, encapsulation, nodulation and proPO-AS release [66-68]. Furthermore, non-opsonin-mediated phagocytosis is an ancient form of pathogen recognition that is mediated by the direct interaction of hemocyte membrane receptors with pathogen surface molecules. In Drosophila, the scavenger receptor Eater is expressed by hemocytes [69], and its $\mathrm{N}$ terminus is responsible for direct binding to microbes. Therefore this membrane protein plays a key role in the removal of Gram-positive and Gram-negative bacteria [69].

One of the most intriguing discoveries of recent years was that of the evolutionarily conserved Toll and Imd pathways (Figure 4), found in Drosophila [70,71] and humans [34]. Toll is a transmembrane receptor with an extracellular domain rich in leucine repeats, whereas the intracellular region has a significant homology with the corresponding region of the Interleukin-1 receptor (IL-1R); this part of the receptor is referred to as the TIR domain (Toll-IL-1R). Toll receptors are expressed either on fat bodies or epithelial cell membranes after stimulation by fungi or Gram-positive bacteria [72]. The interaction of Toll receptor with its extracellular ligand Spätzle (Spätzle is turned into its active form when PRR-PAMP interactions led to activation of serine protease) leads to activation of an intracellular cascade, which culminates in the activation of antimicrobial peptides-coding genes (Figure 4, left panel). A second pathway (Figure 4, right panel), the immune deficiency pathway (Imd) is activated when Gram-negative bacteria infect the host [73]. While the Imd intracellular transduction pathway is well known [72] and several cellular sensing receptor(s) have been identified [74], the complete picture is far from being elucidated. Evidence seems to indicate that PGRPs (peptidoglycan receptor proteins) may be key receptors for peptidoglycans of Gram-negative bacteria [75-77].

Insect mutants for Toll and Imd genes were found to be differentially susceptible to fungal and bacterial infection [78-80]. In these mutants, the Imd and Toll pathways do not appear to share any 
intermediate components and mediate differential expression of AMP-encoding genes via distinct NF-kB-like transcription factors [71]. So far, Toll and Imd pathway cellular receptors could be considered as the main receptors involved in PAMP sensing at a cellular level [81]. Their role is not limited to AMP gene activation [82,83], but, from an evolutionary standpoint, they represent a further confirmation of the ancient origin of innate immunity [84], and a study model that may be used to progress our understanding of a unifying concept of an innate immune response common to all metazoans.

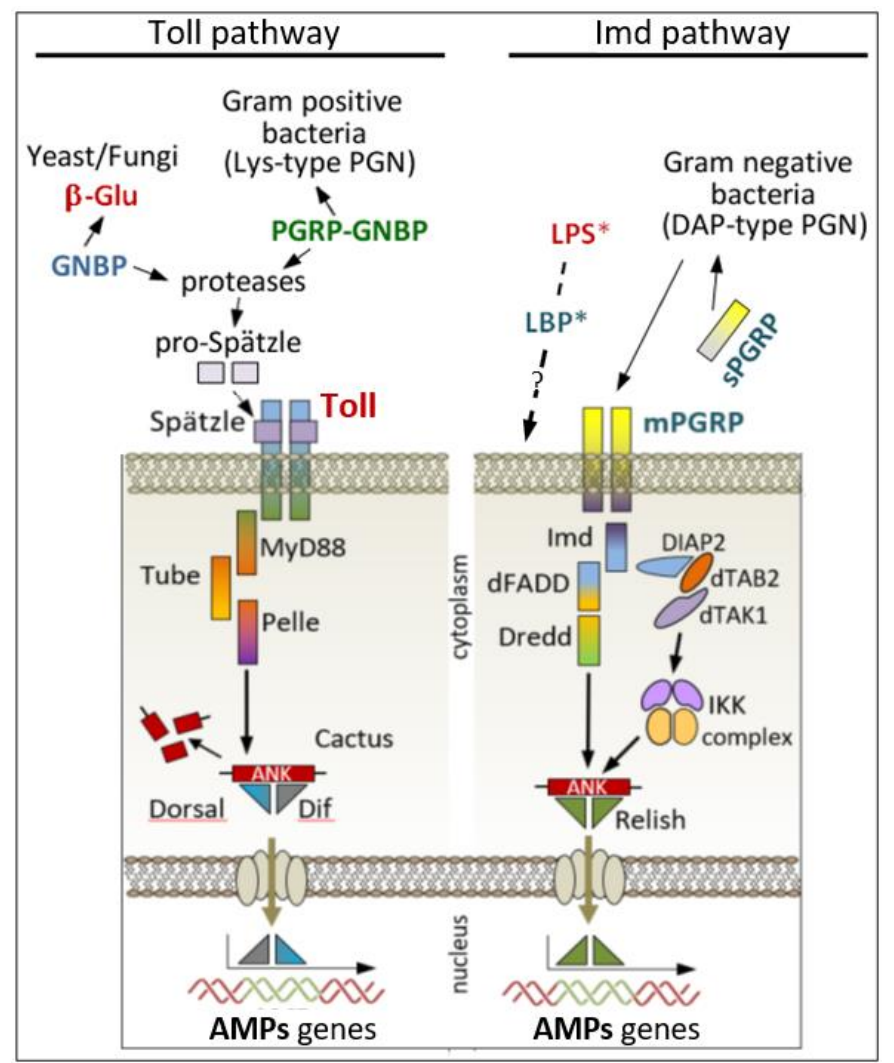

Figure 4. Cellular PRRs: Toll and Imd pathways. (Left) a schematic view of fungine and Gram-positive bacteria stimulation of Toll pathway; the intracellular signal transduction involves adaptor proteins as MyD88, Tube and the serine/threonine protein kinase Pelle. Upon activation, Toll receptor-adaptor complex signals to a latent transcriptional factor, belonging to the NF-kB-Rel family, NF-kB factor is normally complexed to an inhibitor protein (IkB-like) named Cactus. The Toll signaling induces the degradation of Cactus and dissociation from Rel family proteins (Dorsal and Dif). Dif, a member of NF-kB-like proteins, seems to be the main transactivator factor responsible for antifungal and anti-Gram positive bacterial defenses. Dif translocates into the nucleus and switches on many AMPs (antimicrobial peptides) genes, probably several hundred, that in concert contribute to challenge microbial infection. (Right) the Imd pathway stimulated by Gram negative bacteria. The Imd gene encodes a $25 \mathrm{kDa}$ protein with a death domain, the protein acts upstream of an adaptor protein named FADD; furthermore, for a full activation, a caspase-8 like protein is required (Dredd). Dredd can directly activate REL protein (Relish). Finally, Rel domain after cleavage, moves to the nucleus and activates AMPs genes. Otherwise, Relish can be phosphorylated by IKK signaling complex, which is itself activated by Tak1 (a MAP kinase) interacting downstream of Imd/FADD.

\subsection{Effector Processes}

Insects defend themselves from challenge by microorganisms or parasites using a combination of humoral and cellular responses (Figure 5) by means of effector processes triggered following interaction between their receptors and foreign molecules. 
However, the distinction between these two processes is rather artificial, as infection elicits a complex of responses that are mostly coordinated and cooperative to fight potential invaders. In addition, immunocompetent cells, even if mainly responsible for cell-mediated immunity, can release soluble compounds belonging to the humoral factor pool. However, to simplify these responses is useful when considering cellular and humoral immunity as separate topics.

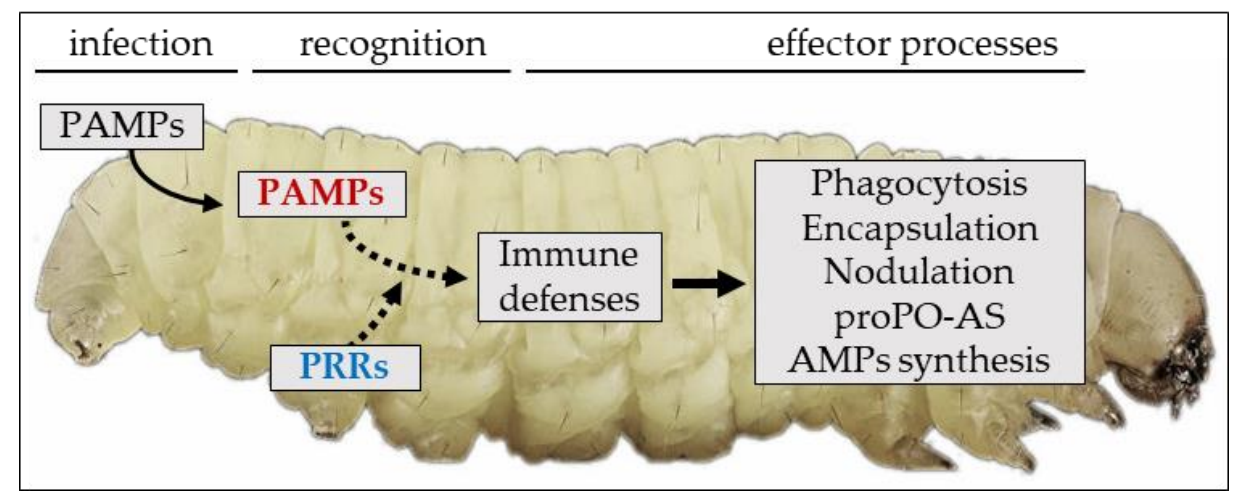

Figure 5. After entry, PAMPs interact with hemolymph and cell-membrane receptors (PRRs) triggering humoral and cellular defenses of the insect host.

\subsection{Humoral Defence}

The circulating fluid of insects is called hemolymph, and unlike blood, it is not confined within vessels but freely distributed in an open circulatory system. Hemolymph plays a key role in transport and storage of nutrients and hormones. In addition, a large pool of soluble factors is synthesized and released by hemocytes and functions as immune molecules that cooperate in both recognition and elimination of invaders. Among these, components such as lysozyme, phenoloxidase and AMPs, contribute to the elimination of non-self.

\subsection{Melanization}

An important process among insect humoral responses is melanization which is responsible for the formation of melanin coats surrounding foreign bodies. This defense mechanism, called humoral encapsulation $[67,85]$, is efficacious and usually faster than cell-mediated processes. The penetration of metazoan or bacteria can elicit the activity of the proPO-AS, the main function of which is the synthesis of melanin in the process of humoral encapsulation (Figure 6A). This enzymatic cascade is extremely reactive, since it can also be activated in the presence of inert materials such as charged microbeads (Figure 6B).
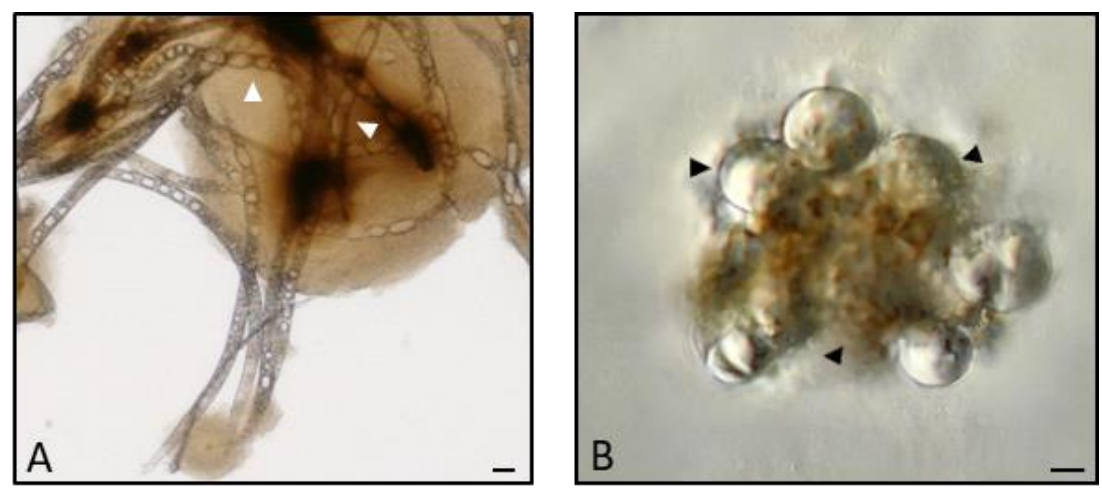

Figure 6. (A): Free-living nematodes (Panagrolaimus rigidus) incubated with cell-free hemolymph, arrowheads indicate melanin-trapped worms. (B): Humoral encapsulation of synthetic microbeads. Bars $=50 \mu \mathrm{m}$. (unpublished images by Brivio [86]). 
The melanization reaction, which is a common response to the presence of non-self in invertebrates (especially arthropods), is due to the activity of an oxidoreductase called phenoloxidase. This molecule is the terminal enzyme of a complex system of proteases, proteases inhibitors (serpins) and humoral PRRs, constituting the proPO-AS. proPO-AS is proposed to be a system of recognition of non-self, since the conversion of prophenoloxidase to active enzyme can be easily achieved by foreign molecules such as LPS, PGNs and $\beta$-1,3-glucans [87].

Prophenoloxidase is converted into its active form by a limited proteolysis, and when activated, phenoloxidase can oxidize phenols into quinones that in turn autocatalyze into melanin $[87,88]$. proPO-AS is a key element in the recognition of foreign bodies and it is also involved in production of opsonic factors; it is now considered to represent an integral component of the insect immune system [89-91]. Several hemolymph molecules, functioning as PRRs, are involved in proPO-AS (Figure 7), among them $\beta$-1,3-glucans-binding proteins ( $\beta$-GBP), LBPs and PGRPs, seem to play key roles as receptors triggering the protease cascade $[87,92,93]$.

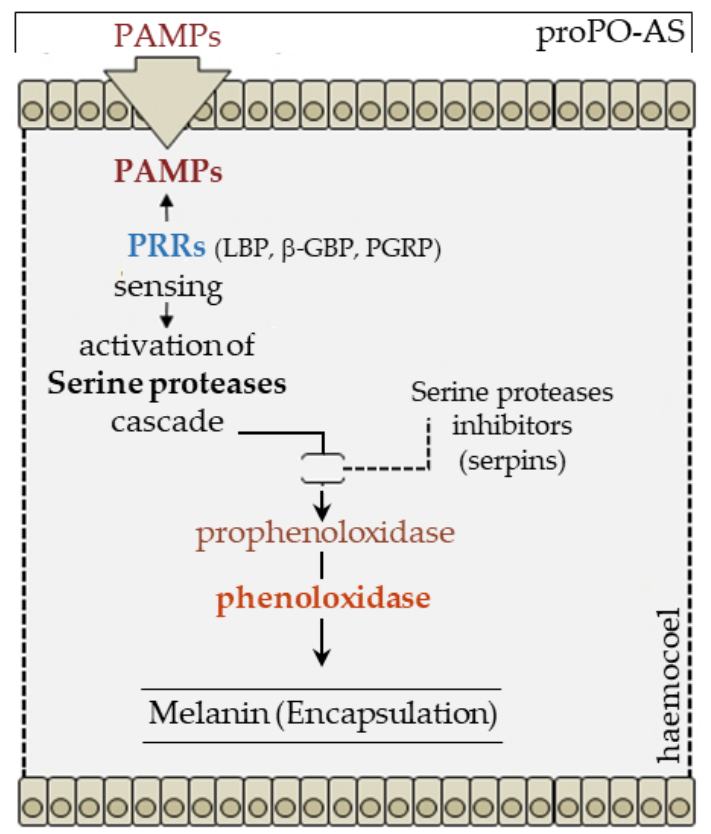

Figure 7. Insect proPO activating system is strongly elicited by the presence of PAMPs, prophenoloxidase zymogen, after PRRs-PAMPs interaction, is activated by serine proteases cascades; physiological negative control (serpins) provide the downregulation of the enzyme activity to turn-off the system when not required. The system is responsible of humoral melanization (melanin encapsulation) of foreign targets.

\subsection{Antimicrobial Peptides and Bacterial Clearance}

Insect antimicrobial peptides (AMPs) are synthesized in fat body tissues (comparable with the vertebrate liver) and released into the hemolymph during a systemic response against pathogens. The sensing of foreign bodies culminates in the synthesis, ex novo, of AMPs. Thus, these are considered to be inducible factors. Their occurrence is consequent to the activation of immune genes mediated by evolutionarily conserved Toll/Imd pathways present in both vertebrates and invertebrates.

AMPs are strong cationic, heat stable and amphipathic molecules that have a variable amino acid composition, length (30-60 aa) and structure.

Despite their structural variety, AMPs are able to affect a large number of microorganisms [94,95]; for example, positively charged peptides interact directly with the anionic moiety of bacterial membranes (e.g., LPS, lipoteichoic and teichoic acids), inducing an increase in membrane permeability that leads to rapid cell death $[95,96]$. When fat body cells are stimulated by the presence of foreign compounds, intracellular pathways (Toll/Imd) become active and AMP gene transcripts led to the 
synthesis of a pool of antimicrobial peptides active against Gram-negative and Gram-positive bacteria, fungi and yeast [97]. Following table (Table 1) summarizes some characteristics of AMPs isolated from insects.

Table 1. Example of some insects' antimicrobial peptides (AMPs).

\begin{tabular}{cccc}
\hline & Amphipathic Linear Peptides & \\
\hline Name & Source & Size (aa) & Activity \\
\hline Cecropin & Lepidoptera, Diptera & $31-39$ & Gram negative/positive \\
Moricin & Lepidoptera & 42 & Gram negative/positive \\
Mellitin & Hymenoptera & 26 & Gram negative/positive \\
\hline \multicolumn{4}{c}{ Cyclic Cysteine Rich Peptides } \\
\\
\hline Defensin & Diptera, Hemiptera, Coleoptera, Lepidoptera & $32-43$ & Gram positive/negative \\
Drosomycin & Diptera & 44 & Fungi \\
\hline Drosocin & Peptides Rich in Specific Amino Acids & \\
Diptericin & Diptera & 19 & Gram negative \\
Attacin & Diptera & $100-110$ & Gram negative \\
Coleptericin & Lepidoptera & $214-224$ & Gram negative \\
Gloverin & Coleoptera & 74 & Gram negative \\
\hline
\end{tabular}

Data summarized from [95]. *, from https://www.ncbi.nlm.nih.gov/protein.

The activity of AMPs against bacterial walls is supported by the action of lysozyme, a constitutive enzyme that hydrolyses bacterial wall peptidoglycans [98]. Lysozyme is described as a constitutive factor whose concentration is related to the increase of bacteria in the host body. Physiologically, AMPs production (Figure 8) and upregulation of lysozyme synthesis reflect the requirement of insects to fight infection and to avoid the risk of septicemia.
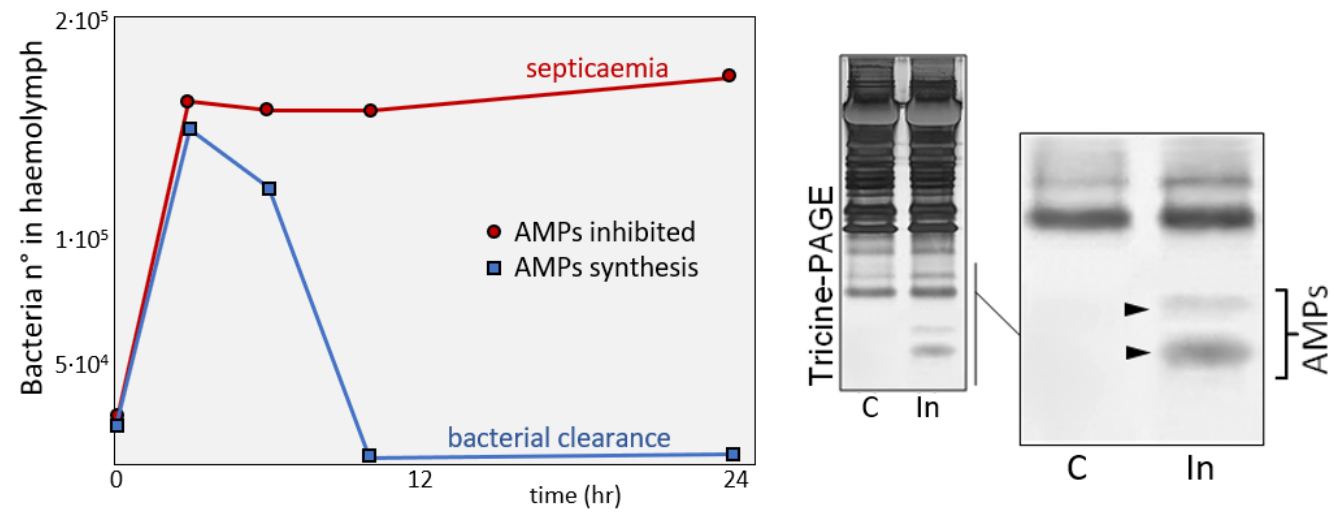

Figure 8. (Left) effects of AMPs synthesis after bacterial infection; insect larvae when inoculated with bacteria show an efficient bacterial clearance by means of newly synthesized AMPs (blue line). If the infection was carried out in the presence of inhibitors of protein synthesis (red line), AMPs were absent, and the larva showed symptoms of septicemia disease. (Right) Electrophoretic analysis of hemolymph samples from not infected (C) and infected (In) G. mellonella larvae. Arrowheads indicate the presence of two low molecular mass bands in the hemolymph from immunized larvae, (from [99]).

\subsection{Cellular Defenses}

Many studies on insect immunity have been performed to identify immunocompetent cells and understand their functions when in the presence of non-self invaders [65,100].

Hemocytes are circulating cells that play a key role in preserving host integrity, and they are involved in cellular mechanisms such as phagocytosis, nodule formation, encapsulation, cell-mediated melanization and synthesis of antimicrobial peptides [36,101,102]. Therefore, hemocytes are directly responsible for the elimination of foreign bodies such as bacteria, fungi, nematodes etc. 
Circulating cells within hemolymph consist of several populations that are classified according to morphological, histochemical, immunocytochemical and functional features [103-105]. Common types of hemocytes, described in Lepidoptera (Figure 9), are the pro-hemocytes, granulocytes, plasmatocytes, spherulocytes and oenocytoids [106-109].

Classification of insect hemolymphatic cells is somewhat different in Dipterans, where lamellocytes and cells with crystalline inclusions (crystal cells) have been described in addition to plasmatocytes $[100,110]$. During insect embryogenesis, a fraction of cells develops from the head or from the dorsal mesoderm; the tissue continues to produce hemocytes during larval or nymphal stages via division of stem cells in the hemopoietic organs and/or by continued division of hemocytes already present in the hemolymph [111-113].

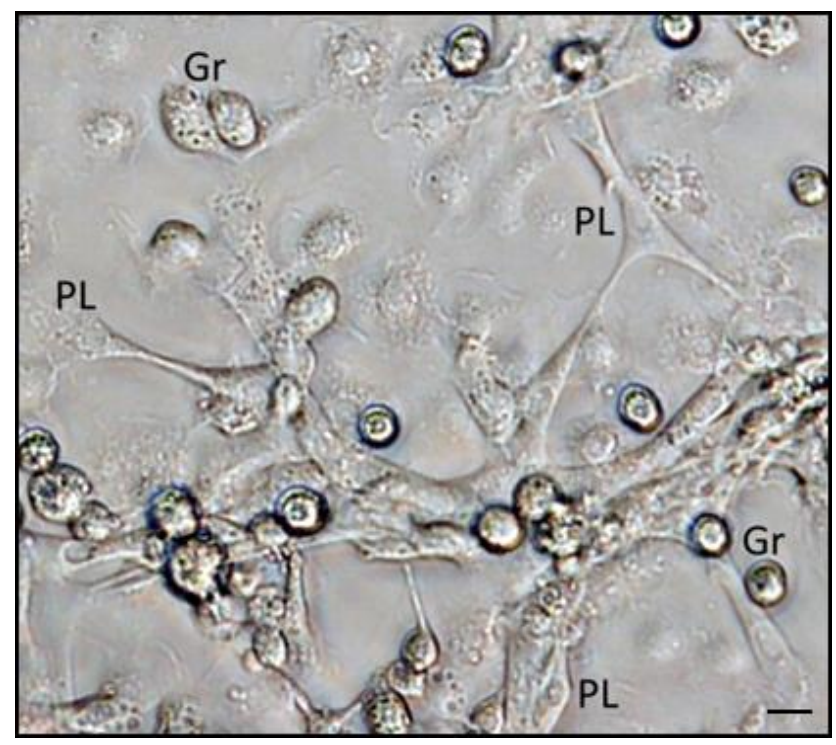

Figure 9. Nomarski Interference Contrast (NIC) micrograph of a culture of G. mellonella hemocytes: Adherent plasmatocytes (PL) and many reacted and not-reacted granulocytes (Gr) are observable. Bar $=50 \mu \mathrm{m}$, (Unpublished micrograph by Brivio [86]).

Pro-hemocytes, are an immature form of hemocytes, they seem to represent stem cells able to differentiate into one or more cell types. In the larval stage, granulocytes and plasmatocytes are the most abundant cell type in Lepidoptera, and are known to be capable to recognize, adhere to and spread on foreign surfaces, otherwise not-adherent cells, spherulocytes, oenocytoids and pro-hemocytes represent a small fraction of the circulating hemocyte population [114].

When foreign organisms breach the outer physical and chemical barriers of an insect and penetrate its hemocoel cavity, the cellular components of the host immune system may be rapidly mobilized and a struggle for survival ensues.

\subsection{Phagocytosis}

The primary response of hemocytes to small particles, such as bacteria, yeast, or protozoa, is phagocytosis, a process that can be envisioned as a specialized form of receptor-mediated endocytosis. The process of phagocytosis, from insects to mammals, appears to be very similar [115]. In both cases, binding of opsonic ligands to the surface of the particle occurs, which is then followed by receptor-mediated recognition and subsequent activation of signaling pathways resulting in the internalization of the foreign body $[116,117]$.

In insects, both granulocytes and plasmatocytes have been reported to be able to phagocytize (Figure 10); the efficacy of phagocytosis depends on the structure of the surface of the foreign organism and on the involved hemocytes. 

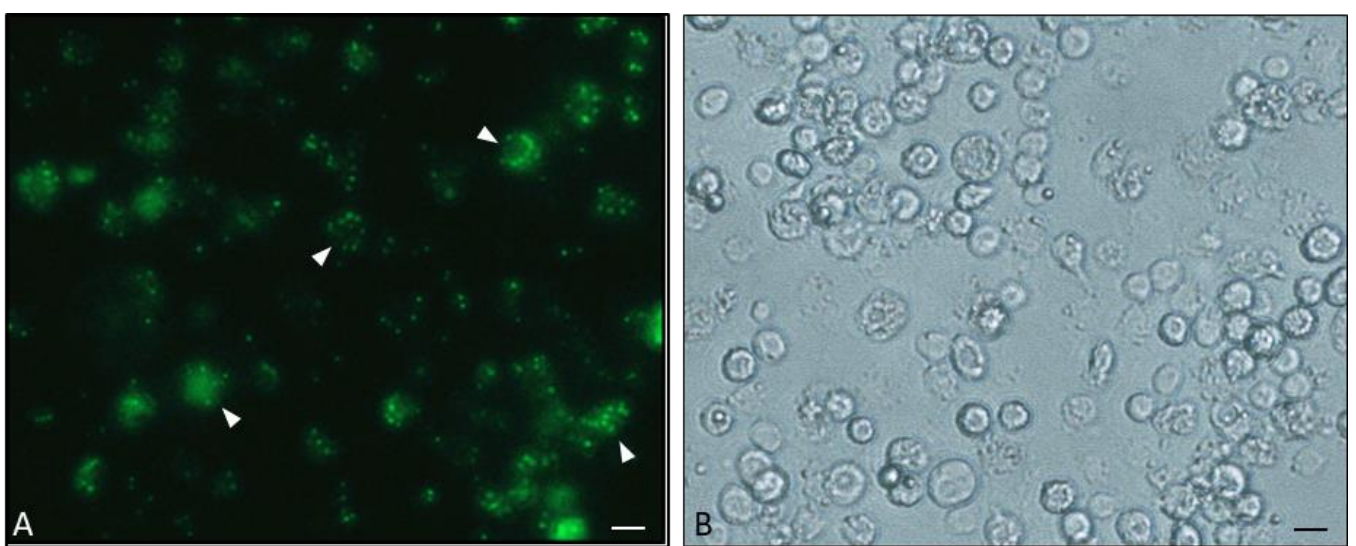

Figure 10. An example of in vitro phagocytosis. (A): Fluorescein Isothiocyanate (FITC)-conjugated Escherichia coli cells (arrowheads) are engulfed by lepidopteran hemocytes (he). (B): brightfield image. Bars $=50 \mu \mathrm{m}$, (unpublished micrographs by Brivio [86]).

In addition, the presence of microbial factors, such as glucans, PGNs or LPS, can increase the phagocytic rate of hemocytes. Moreover, lectins (or lectin-like molecules) can play a role in the opsonization of non-self; in general, phagocytosis can be enhanced by the interaction between foreign sugars (free or conjugated oligosaccharides) and hemolymph sugar-binding proteins [118].

Finally, the process may be stimulated by the same components released after proPO-AS activation [119]. In the presence of many bacterial cells (or large amounts of free LPS) or fungi, hemocytes degranulate releasing humoral factors that form aggregates, called nodules [68], this process leads to the entrapping of foreign cells. Such nodular aggregates may adhere to host tissues and larger nodules may eventually be encapsulated by the hemocytes [120].

\subsection{Encapsulation}

When protozoan, metazoan parasites, eggs or larvae and foreign invading organisms or abiotic particles are too large to be phagocytized, they can be encapsulated by multiple layers of hemocytes. These hemocytes can produce a coat of melanin in the late stage of the process and this process is named cellular encapsulation (Figure 11).

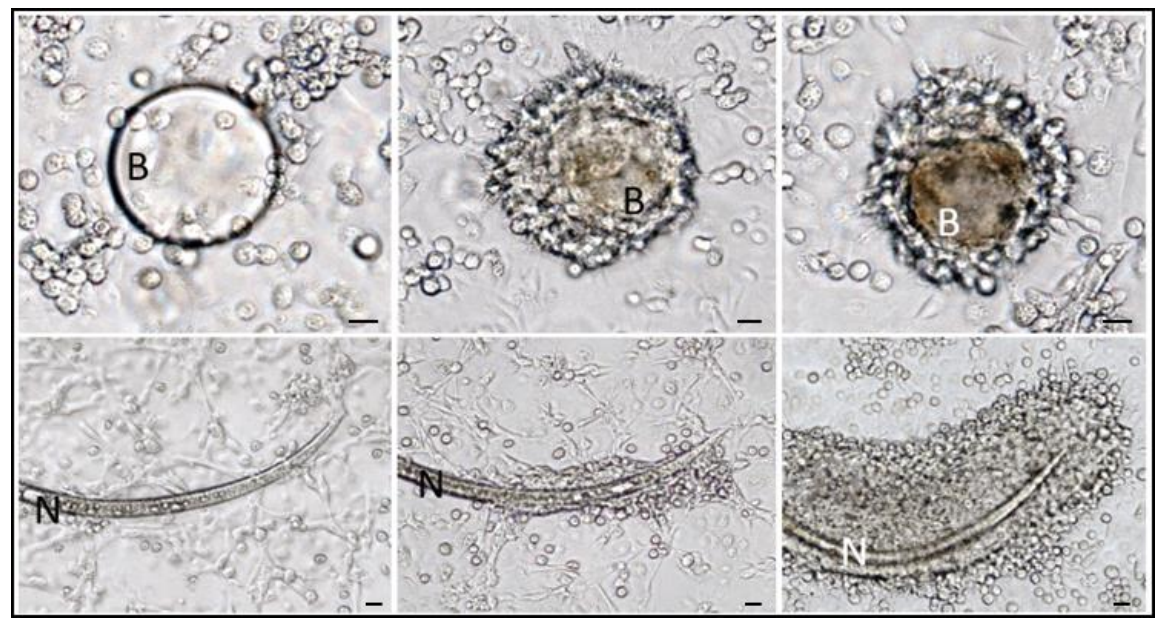

Figure 11. G. mellonella hemocytes forming capsule around abiotic materials and free-living nematodes. (Upper) panels show encapsulation steps from 1 to $8 \mathrm{~h}$ after incubation of cultured hemocytes with synthetic beads (B); in the right micrograph is evident the melanin deposition around the bead inside the inner cell layer. In (lower) panels the same experiment was carried out with free-living nematodes $P$. rigidus $(\mathrm{N})$. In both assays the progressive formation of multi-layered cellular capsules is observable. Bars $=50 \mu \mathrm{m}$ (from [121]). 
The formation and growth of cellular capsules mainly requires two cell types: granulocytes and plasmatocytes $[100,113]$. Usually, the formation of a capsule begins within $30 \mathrm{~min}$ from the entry of a foreign body and the early steps involve granulocytes and humoral pattern-recognition receptors (PRRs) as opsonic factors. In sequence, granulocytes release chemotactic components, called plasmatocyte-spreading peptides (PSP), that attract plasmatocytes and increase their adhesive properties [122-124].

As mentioned above, humoral factors may also be involved in encapsulation. In particular, in the early recognition and binding of PAMPs, different studies have demonstrated that humoral PRRs are needed to stimulate the aggregation of plasmatocytes on the surface of the target or to the earlier layers of the granulocyte capsule $[67,101]$. The cooperation between these immunocompetent cells results in a multicellular layered thick capsule that segregates the foreign organism, avoiding trophic exchanges with the host body environment. Moreover, the toxic effects of melanin, which is present inside the inner layers of the capsule, may contribute to kill the entrapped organism [125-128].

\section{An Overview of Parasites' Strategies}

Since the effectiveness of insect immune defenses has been exhaustively described, how can EPNs overcome/avoid the host defensive processes? The two main strategies by which EPNs avoid and counteract the host immune defenses are molecular mimicry processes and immune suppression, these strategies can be particularly effective when they penetrate young hosts with a low level of immune competence; however, EPNs are commonly able to invade both adults and dead hosts [129-131].

In general, mimicry processes can be realized by the synthesis of molecules that are antigenically related to the host (usually named self-proteins), and are exposed on the parasite body surface [132-134]. Otherwise, mimicry could be a form of disguise based on the acquisition of host molecular compounds or tissues which overlay the parasite body surface $[32,135,136]$. Moreover, depression of host defenses is usually achieved thanks to the excretion/secretion of various compounds that interfere with and neutralize many effector processes elicited by the host in response to infection $[137,138]$.

Many studies have described the strategies implemented by EPNs and their symbiotic bacteria to survive and reproduce inside their insect hosts and it is commonly accepted that the main strategies are immune evasion and immunosuppression.

In the early phase following infection ( 0 to $2 \mathrm{~h}$ ), to overcome host defenses, the worms use a type of mimicry to become unrecognizable to proPO-AS and to the immunocompetent hemocytes; in subsequent phases, both nematodes and symbiotic bacteria use active strategies aimed to depress humoral and cellular responses, based on the release of toxins, inhibitors and proteases. The nematocomplexes behave like Trojan horses, carrying and releasing their symbionts inside the host's hemocoelic cavity; thus, Xenorhabdus, when in the hemolymph, need to be unrecognized in the early stages of infection. The following scheme (Figure 12) describes the sequence of events following the penetration of EPNs in the host.

In this review we describe the behavior of two EPNs belonging to the same genus, Steinernema feltiae and Steinernema carpocapsae, that are associated with the symbiont bacteria Xenorhabdus bovienii and Xenorhabdus nematophila, respectively. These EPNs, by means of different elusive strategies, achieve a successful life cycle inside their insect hosts. 


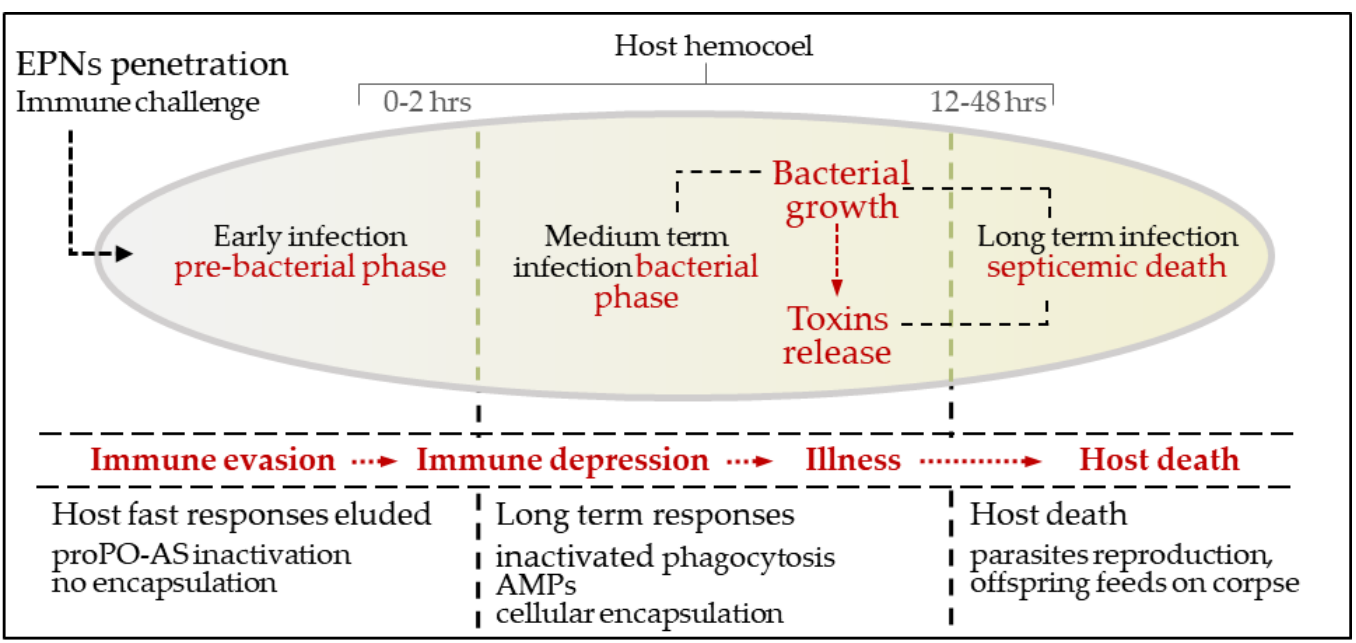

Figure 12. EPNs: time course of EPNs infection, modulation of immune response and host death.

\subsection{S. feltiae: Host Immunomodulation}

In this section we describe the effects induced by $S$. feltiae after penetration of the hemocoel of G. mellonella. The main features of this EPN are the effects of the elusive processes by which the worm interferes with the host immune responses; in these processes the body surface of nematodes (epicuticle/cuticle) plays a central role and its involvement has been described by various authors $[139,140]$. A general model of the immune-evasive role of the nematode cuticle was proposed by Blaxter et al. [141], despite the fact that different species show differences in their molecular architecture and properties. In addition, the epicuticular outer layer can be modified in composition and organization, and in relation to the host internal milieu, EPNs molt multiple times during their life cycle. Each time they molt, they change their body surface, building a new cuticle and epicuticle. Cuticles of various parasitic nematodes, with other surface and secreted molecules, participate in immune evasion and suppression of host defenses [142,143].

A specific role for the $S$. feltiae epicuticle has been suggested by Dunphy and Webster [144]. The authors described the lack of encapsulation by G. mellonella hemocytes and presumed that the lipidic moiety present in the epicuticle of the nematode could be responsible for this process. Indeed, they observed that the treatment of the cuticle with lipases caused the loss of its elusive properties; they supposed that the alteration of the cuticular lipids led to the unmasking of discriminable antigens.

Unlike S. carpocapsae, S. feltiae does not seem to use secretion processes to induce host immunosuppression, thus if depressive phenomena are observable, before bacteria release, they can reasonably be attributed to the parasite body surface.

As discussed above, some papers proposed an intriguing hypothesis by which some unidentified molecular components, present on the body surface of the EPN, could play a role not only in the mimicry processes, but also in the depressive phenomena that are observed in the early stages after the penetration of the nematocomplex. Relying on those assumptions, knowledge of the relationship between the body surface of the parasite and the immune responses of the insect host have been extensively investigated [145]; authors defined a temporal interval that allowed them to exclude the action of the symbiont bacteria (before their release), i.e., a short period in which the observed immunodepressive processes could reasonably be attributed to the nematode itself.

Preliminary observation, obtained with live or dead whole parasites, demonstrated that the worm was unrecognized, did not trigger the proPO-AS (Figure 13, left) and it was not encapsulated by host cells (Figure 13, right); so it was clear that the body surface was able to avoid host immune recognition by means of an elusive strategy. Isolated cuticles from S. feltiae obtained by an improved technique, also confirmed their elusive properties [145]. 

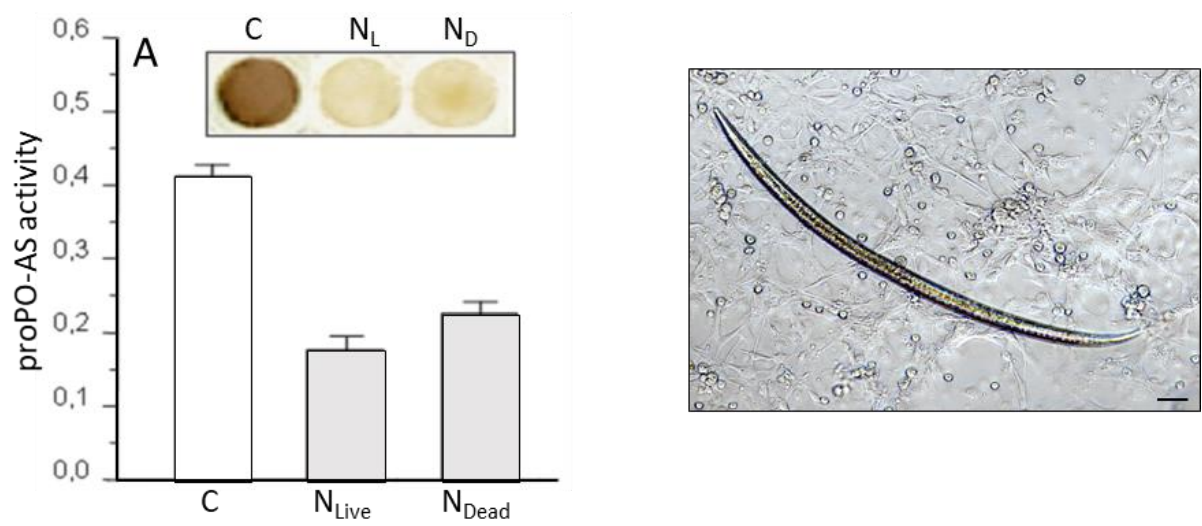

Figure 13. (Left) Effects of the presence of live and dead S. feltiae inside host hemocoel 30 min after infection, the presence of parasites induces a marked inhibition of phenoloxidase activity; the upper box shows the lack of melanin due to the presence of live or dead nematodes $\left(N_{L}, N_{D}\right)$. (Right) Co-incubation of live parasites with G. mellonella cultured hemocytes, showing the absence of cellular encapsulation. Bar $=100 \mu \mathrm{m}$, (from [146]).

The use of cuticles has allowed to exclude any effects due to nematode secretions or to their symbiotic bacteria (Figure 14), and to avoid the use of axenic nematodes which could be physiologically altered because of the absence of their symbionts. Thus, in the presence of the parasite cuticle, a drastic immunodepressive effect was observed, and the inhibition of the host proPO-AS was evident either after in vivo cuticle injection or in vitro co-incubation with hemolymph (Figure 14, left, cut). The molecular architecture of the cuticle and epicuticle is critical to preserve immunosuppressive effects because chemical alterations cause a loss of their properties (Figure 14, left). Confirming Dunphy and Webster suggestions [144], Brivio et al. [146] demonstrated a key role of the surface lipidic moiety, since its removal or alteration by lipases (cut ${ }_{\mathrm{LP}}$ ) or methanol-chloroform ( $\mathrm{cut}_{\mathrm{MC}}$ ) treatments, made the cuticles detectable by the host immune system.
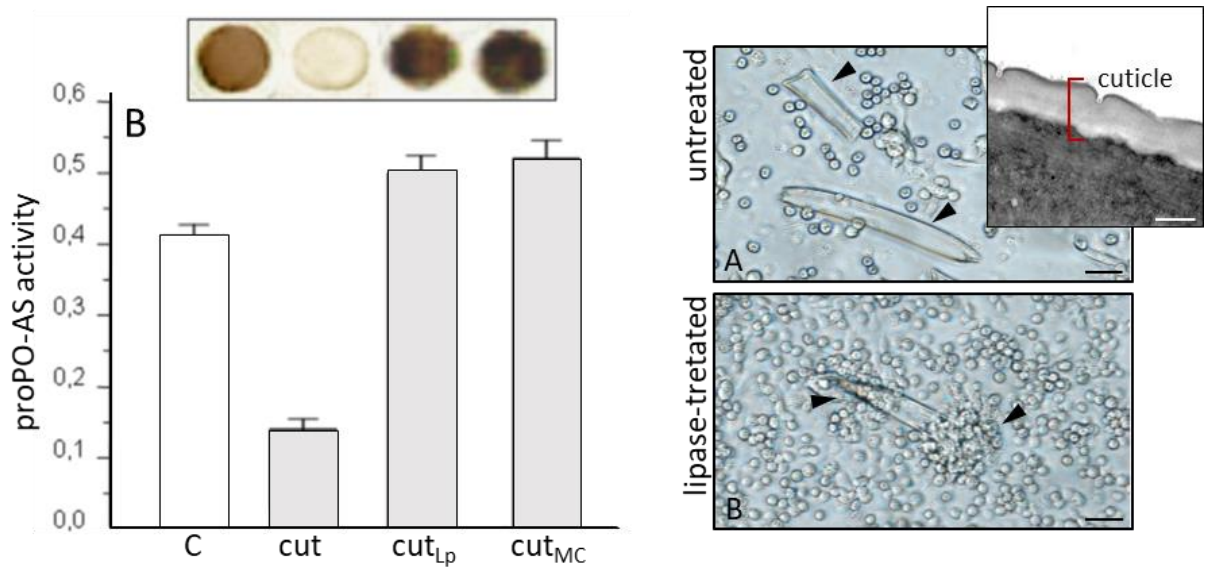

Figure 14. (Left) inhibitory effects induced by isolated S. feltiae cuticles (cut) compared to the basal PO activity $(\mathrm{C})$. The damage of cuticle lipids by lipase treatments (cut $\mathrm{Lp}_{\mathrm{p}}$ ) or methanol-chloroform extractions $\left(\mathrm{cut}_{\mathrm{MC}}\right.$ ) resulted in a marked activation of the host proPO-AS. The upper box shows the lack of melanin synthesis in the insect hemolymph due to the presence of isolated cuticles (cut), melanin was evident when the hemolymph was incubated with treated cuticles (cut $t_{\text {pp }}$ and cut $\left._{M C}\right)$. (Right) co-incubation of untreated and lipase-treated cuticles with G. mellonella hemocytes; untreated cuticles are not recognized and encapsulated; instead, when they were treated with lipases, migration of hemocytes and encapsulation were observed. Inset: TEM micrograph of the S. feltiae cuticle/epicuticle in peripheral region of body. Black bars $=100 \mu \mathrm{m}$; white bar $=500 \mathrm{~nm}$, (from [146]). 
As observed with whole nematocomplexes, isolated cuticles were not recognized by host hemocytes (Figure 14, right, untreated) while lipases treatments induced the loss of their elusive properties (Figure 14, right, lipase-treated).

The inactivation of the proPO-AS involved both cuticle lipids and host PRRs, since the surface of S. feltiae showed specific affinity for some PRRs (named host-interacting proteins, HiPs) (Figure 15A, cut). Removal of the HiPs from hemolymph led to a negative modulation of various immune pathways [146]. Assays based on in vitro interactions between S. feltiae and host hemolymph (Figure 15A, HiPs) demonstrated the specific binding to the cuticle of HiPs. In particular, the surface lipids interacted with and removed some hemolymph proteins $(17,26,35 \mathrm{kDa})$ involved in the proPO-AS pathway.
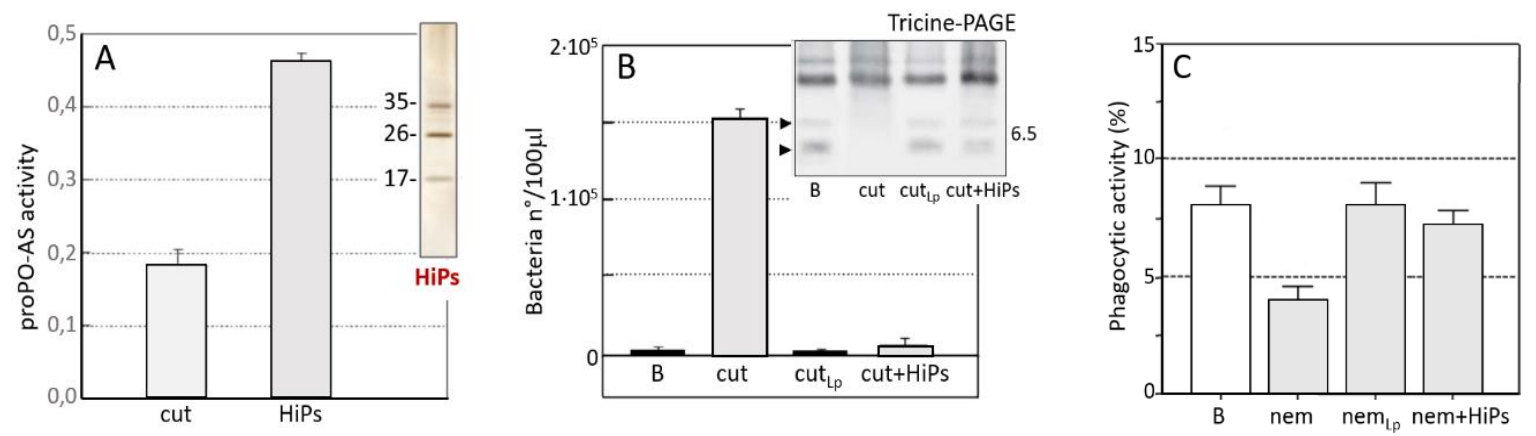

Figure 15. Effects of $S$. feltiae and its cuticles on the host immune processes. (A): The activity of host proPO-AS, inhibited by the presence of $S$. feltiae cuticles, was restored by the addition of host-interacting proteins (HiPs) eluted from the parasite surface after co-incubation with host hemolymph. Inset: an SDS-PAGE of HiPs. (B): The presence of cuticles interferes with AMPs synthesis, since a marked growth of bacteria in the hemolymph from cuticle-injected larvae is observable (cut). Treatments with lipase $\left(\mathrm{cut}_{\mathrm{Lp}}\right.$ ) or addition of HiPs (cut + HiPs), result in a marked bacterial clearance. Inset: presence/absence of AMPs bands after Tricine-PAGE analysis of hemolymph. (C): effects of S. feltiae on phagocytic activity of G. mellonella in the presence of: untreated nematodes (nem), lipase-treated nematodes (nemLp), nematodes plus purified HiPs (nem $+\mathrm{HiPs}$ ). The presence of nematodes significantly reduces the phagocytosis, lipase treatments or HiPs addition, restore the phagocytosis activity, (from $[99,146]$ ).

Some PRRs, with molecular masses similar to the G. mellonella HiPs, have been described as proteins responsible for the activation of various immune processes in several insect species [60,61,147-150]. The involvement of HiPs was confirmed since when these components, collected from the parasite surface by high salts elution, were added to in vitro assays, the normal hemolymph phenoloxidase activity was restored (Figure 15A, inset, HiPs,). Concerning the affinity properties of the HiPs, authors assessed their LPS-binding ability by FAR-western and bacteria-binding assays [125], and from these observations they conceived a model in which parasite surface lipids may act as PAMP-like molecules, which interact with the host HiPs resulting in their subtraction from the hemolymph.

Therefore, these interactions hamper the activation of the serine proteases cascade required for proPO activation and melanization.

The interference of S. feltiae in the AMP synthesis pathway has been also described [99]; the effects of the injection of cuticles inside the host hemocoel (followed by infection with exogenous bacteria, Enterobacter cloacae) interfered with AMP synthesis and consequently bacteria grew in the hemolymph (Figure 15B, cut). Otherwise, damaged cuticles lost their inhibitory properties (Figure 15B, cut $\mathrm{LP}_{\mathrm{LP}}$ ) and the co-injection of HiPs restored AMP synthesis (Figure 15B, cut + HiPs). The downregulation of AMPs was also confirmed by the absence of AMP bands (arrowheads) in hemolymph fractions analyzed by Tricine-PAGE, (Figure 15B, inset).

Host HiPs possess a central role as molecular switches of downstream immune processes, because their removal also affects other cell-mediated defensive processes. When larvae were injected with 
dead parasites, followed by fluorescent-conjugated bacteria, a decrease in phagocytosis activity was evident (Figure 15C, nem). In addition, a decrease in the engulfing ability of the host hemocytes induced by the $S$. feltiae cuticle was lost when cuticle lipids were removed (Figure 15C, nem Lp) and, as observed for the proPO-AS and for AMPs, the addition of purified HiPs reactivated the phagocytosis process (Figure 15C, nem $+\mathrm{HiPs}$ ).

The interaction between parasite body surface molecules and host hemolymph components leads to the formation of a host self-protein coat that does not specifically adhere to the nematode. The coat is responsible for the nematode molecular disguise process, and to verify the occurrence of this process, various assays have been performed that clearly showed that Galleria hemocytes are unable to recognize coated $S$. feltiae as non-self. Co-incubation assays with isolated cuticles and abiotic materials provided further evidence that the host cells were healthy and capable of encapsulation [121]. Based on this data and the current literature, we constructed a schematic model of the strategies carried out by S. feltiae, focused on the role of the parasite body surface (Figure 16).

S. feltiae penetration

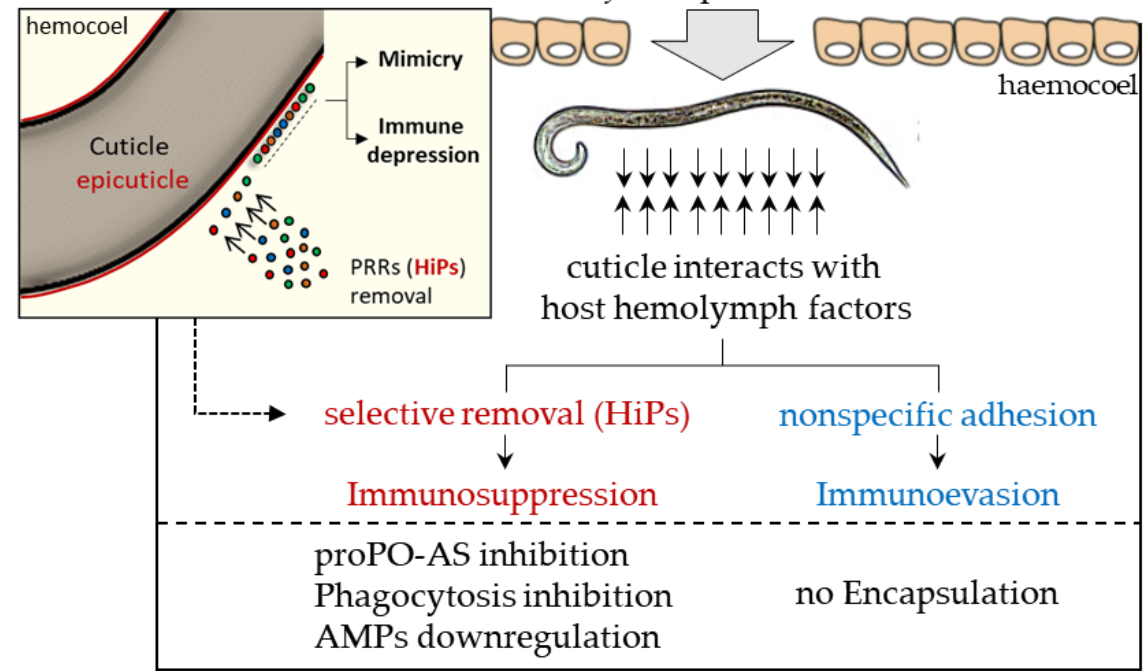

Figure 16. Schematic model of the effects of $S$. feltiae after penetration in insect host. Cuticle compounds remove host humoral factor, inducing immune evasion and depression; particularly, the specific interaction of cuticle lipids results in a selective subtraction of host PRRs (HiPs) leading to a general immune suppression. In addition, the coating of the parasite with host compounds is responsible of its mimicry properties.

In summary, the affinity of the S. feltiae body surface for factors derived from hemolymph of G. mellonella leads to the formation of a coat that surrounds the nematode. This acquired structure performs different functions: the aspecific coating is responsible for a molecular disguise process which makes the nematode self, therefore it is not recognizable by the host's cells (immune evasion).

Among the removed hemolymph components, some show a strong affinity for cuticle lipids, these components (HiPs) are PRRs and function as molecular switches of the proPO-AS, AMPs and phagocytosis pathways. Thus, the selective removal of the HiPs by S. feltiae leads to a general immunosuppression of the host (Figure 16).

From the data on the relationships between S. feltiae and G. mellonella, it is evident how the strategies implemented by this EPN are extremely effective and that the nematode is capable to neutralize the immune defenses of this insect. However, the effects induced by $S$. feltiae can be quite different when investigated in other insect species. S. feltiae was almost unrecognized by the coleoptera Agriotes lineatus hemocytes, the presence of the nematode in the hemolymph decreased the number of total hemocytes and the PO activity $16 \mathrm{~h}$ after injection [151]. Although S. feltiae when invades G. mellonella, promptly induces a decrease in phenoloxidase activity and the nematode avoids 
encapsulation, in other insect species an increase of PO activity and phenomena of encapsulation have been observed. Injection of S. feltiae in Pieris brassicae increases PO activity up to three hours post injection and decreases afterwards [152]; also, in the lepidoptera Helicoverpa armigera the activation of PO was observed $8 \mathrm{~h}$ post injection of S. feltiae [153]. In Popilia japonica (Li et al., 2007) both humoral and cellular encapsulation of S. feltiae have been observed [154]. Moreover, in the Colorado potato beetle Leptinotarsa decemlineata, S. feltiae was markedly encapsulated by hemocytes $24-72 \mathrm{~h}$ post-infection [155].

\subsection{S. carpocapsae: Host Immunomodulation}

As observed for S. feltiae, also S. carpocapsae is able to escape from the immunosurveillance of its insect host. Despite a few exceptions, such as humoral encapsulation observed for the dipteran Tipula oleraceae [156] and cellular encapsulation for the lepidopteran Pseudalaetia unipuncta [157], immune evasion seems to be a common strategy of EPNs. Evasion can arise from the capacity to mimic insect recognition or, by means of a more drastic action, making the host defensive systems ineffective. In the latter case, the parasite strategy involves immunosuppression phenomena.

Wang and Gaugler [158] attributed the ability to mimic insect recognition to specific proteins expressed in the epicuticle of the invasive IJs of S. carpocapsae. Götz et al. [159] showed that axenic S. carpocapsae was able to destroy antibacterial peptides by means of secreted compounds with proteolytic activity, thus compromising the insect's defenses. Other work described a toxic activity of secretions from axenic $S$. carpocapsae $[137,160]$ which, when injected caused insect death after a few hours post-treatment, suggesting that the secretion by the nematode is independent of bacteria release [161]. Even if the lethality of S. carpocapsae is attributed mainly to virulence factors produced by its bacterial symbionts, moderately lethal activity was also observed for insects exposed to axenic nematodes. Further confirmation of the role of $S$. carpocapsae secretion in insect lethality has also been provided by results on the proPO-AS activity (Figure 17) obtained from a study with live or dead nematodes, or isolated cuticles [162] and by a detailed work on secreted compounds isolated from activated nematodes [163].

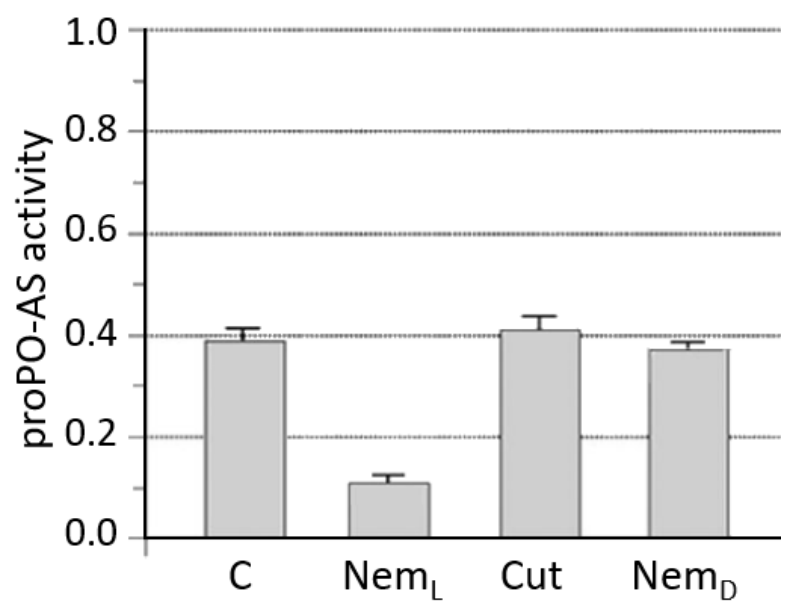

Figure 17. Effects of S. carpocapsae on proPO-AS activity. The presence of live nematodes induces a marked inhibition of the host phenoloxidase activity $\left(\mathrm{Nem}_{\mathrm{L}}\right)$; instead, either dead parasites $\left(\mathrm{Nem}_{\mathrm{D}}\right)$ or isolated cuticles (Cut) do not affect the host proPO-AS. C: basal PO activity recorded as control, (from [162]).

Proteases, apoptosis-inducing factors, protease inhibitors and other active compounds have been suggested to be actively secreted/excreted by parasitic nematodes into host tissues [138,163-165]. In particular, serine, cysteine, metallo and aspartic proteases, deployed by parasitic nematodes, must participate in some of the tasks imposed by the parasitic life cycle, including invasion, digestion of host tissues and evasion of host immune responses (Figure 18) [166-168]. An exhaustive analysis 
of transcripts from parasitic and resistant stages of $S$. carpocapsae has been performed, and authors have identified, by means of a suppressive-subtractive hybridization (SSH) database, various genes associated to pathogenic processes [168-173].

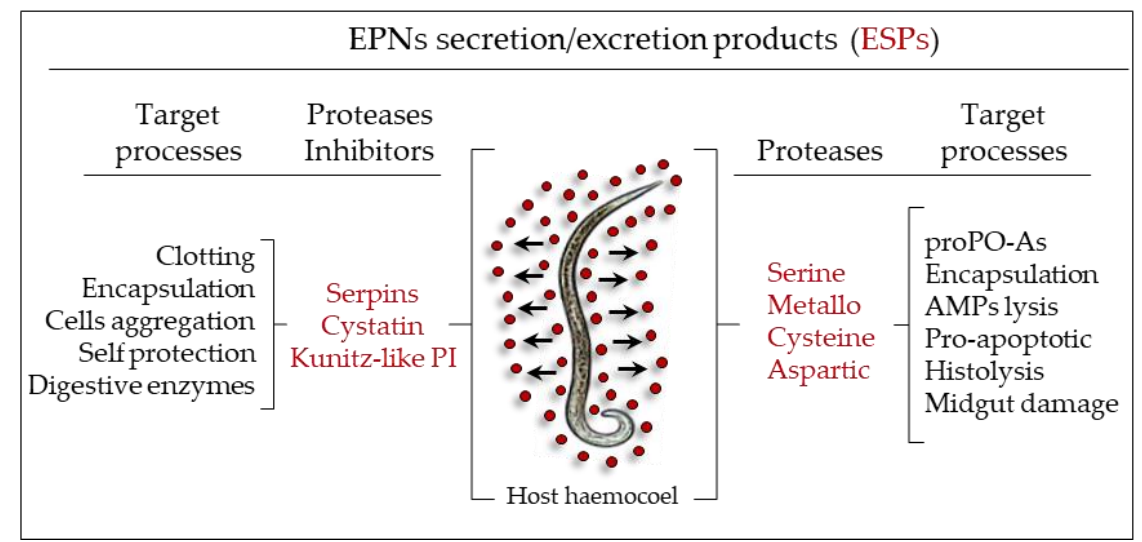

Figure 18. Summary of the effects of secretion/excretion products (ESPs) of S. carpocapsae throughout infection.

A study investigating the possible role of the interaction of surface molecules of $S$. carpocapsae with its hosts, has ascertained the involvement of the cuticle in elusive strategies (Figure 19), aimed to avoid hemocyte recognition and consequently cellular encapsulation [162].

However, regarding immune suppressive properties of the cuticle of $S$. carpocapsae, the current literature provides conflicting data, since modulation of immune responses seems to depend heavily upon the host species considered. In Rynchophorus ferrugineus (Coleoptera), humoral defenses are not counteracted by the presence of the parasite cuticle [162]. Moreover, as recently demonstrated [174] in Drosophila, in the presence of endosymbionts Wolbachia and Spiroplasma, the axenic S. carpocapsae activates proPO-AS and upregulates the Toll pathway.

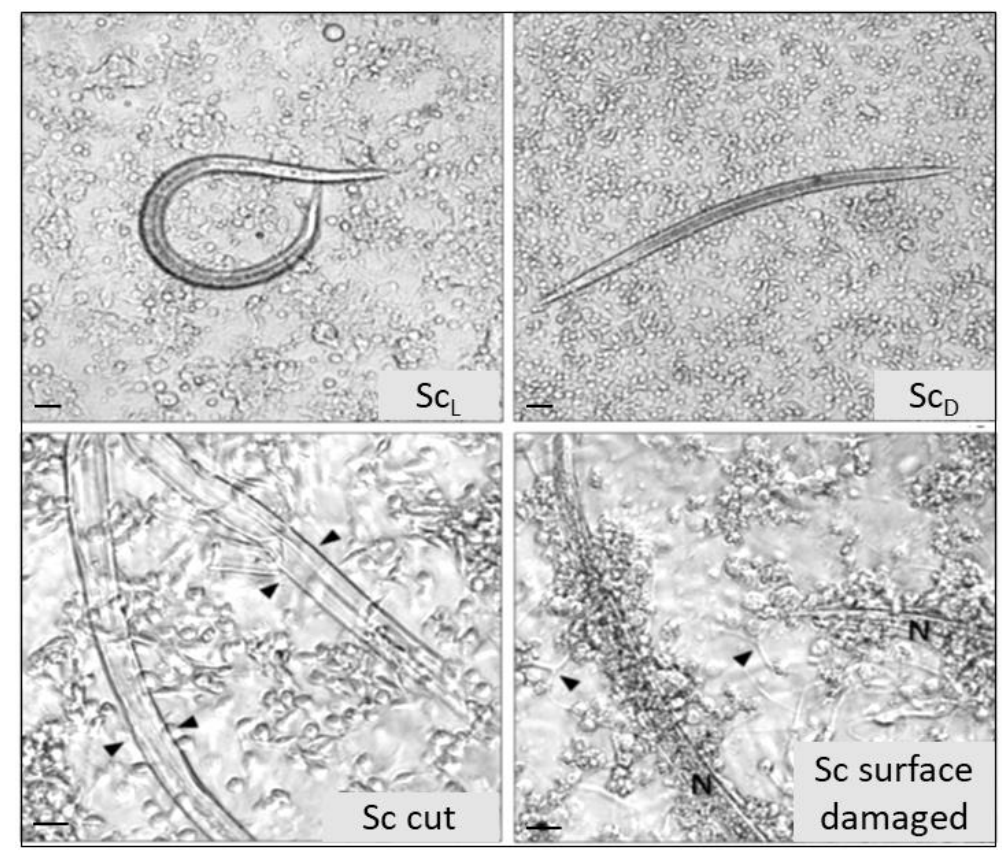

Figure 19. Evasion from encapsulation, of live $\left(\mathrm{Sc}_{\mathrm{L}}\right)$ or dead $\left(\mathrm{Sc}_{\mathrm{D}}\right) \mathrm{S}$. carpocapsae and their isolated cuticles (Sc cut). Chemical damage of the parasite body surface results in the loss of its elusive properties (Sc surface damaged). Bars $=100 \mu \mathrm{m}$ (from [162]). 
In contrast, in G. mellonella, the phenoloxidase activity and other processes are depressed following injection of cuticle derived from S. carpocapsae [175]. S. carpocapsae cuticles do not seem to release exudates with depressive properties [176] even if $S$. carpocapsae high salt-soluble proteins slightly raise the mortality of $R$. ferrugineus hemocytes [177].

In R. ferrugineus larvae, the down-regulation of antimicrobial activity after the injection of live S. carpocapsae or isolated X. nematophila, has been recently observed; since dead nematodes or their cuticles lack inhibitory properties, the observed effects could be ascribed to X. nematophila [178]. Besides, in Spodoptera exigua, treatments with both X. nematophila and its culture broth, inhibited the expression of attacin and cecropin genes [179].

\section{The Role of Bacterial Symbionts}

Symbionts of Xenorhabdus spp. lack a free-living stage and depend on Steinernema spp. nematodes for their propagation among insect hosts. The mutualistic association is species-specific since X. nematophila colonizes S. carpocapsae, and X. bovienii associates with S. feltiae and other Steinernema species $[25,180]$.

Both bacteria exist in two distinct phases [181], called phase I and phase II; phase I is the form of X. nematophila normally associated with the nematode [182], phase II cells may also colonize the nematode [183], but they have never been found associated with naturally occurring nematodes [184]. A different pathogenicity of the two phases has been described [185] and even if phase I is commonly considered as the more virulent, several reports have described a high level of pathogenicity for both the phases [183]. The two phases are distinguishable by several physiological, biochemical and behavioral features, such as dye adsorption, swimming/swarming ability and antibiotic production [181,186].

As previously mentioned, the action of the nematode itself occurs in the early stages of infection but, after a variable time (1-2 h), the nematode begins to release its symbiotic bacteria, from the gut lumen and vesicles, into the circulatory stream of the host. The action of the bacteria, supported by the immunodepressive processes induced by the nematode, culminates in the death of the host due to a severe septicemia. Many studies have described the host physiological disorder caused by the release, proliferation and toxin production from the symbiotic bacteria [187]; in particular these microorganisms seem to rearrange the environment (host's body) in a favorable manner that promotes survival and reproduction of the parasite.

Xenorhabdus spp., upon release into the hemolymph of the host, G. mellonella, adheres to the surface of hemocytes, proliferates and damages the cells, which become vacuolated, unable to adhere to surfaces and finally die $[186,188,189]$. At the same time, Xenorhabdus synthesizes and release antibiotic compounds within the insect hemocoel that suppresses competing microorganisms [190]; in this way they acquire conditions that promote their own proliferation and allow the parasites to complete their development $[4,191]$. When in the virulent phase, Xenorhabdus demonstrates a typical morphological phenotype recognizable by the presence of various surface structures such as pili/fimbriae, flagella and the outer membrane vesicles (OMVs) containing virulence factors [192-194]. These structures interact with the host and affects their recognition by hemocytes; they also prevent phagocytosis and nodulation processes (pili/fimbriae), promote adhesion and invasion of host tissue (flagella), or release proteases, lytic factors and phospholipase C (OMVs), therefore contributing to larvicidal activity [177].

The lethal action of the symbiotic bacteria is therefore achieved through the immunoevasive/depressive and toxic action of both the external structures and of the secondary metabolites secreted by the bacteria, and the overall action of these toxic components causes a severe metabolic and functional disorder that leads to death by septicemia of the insect target (Figure 20). 


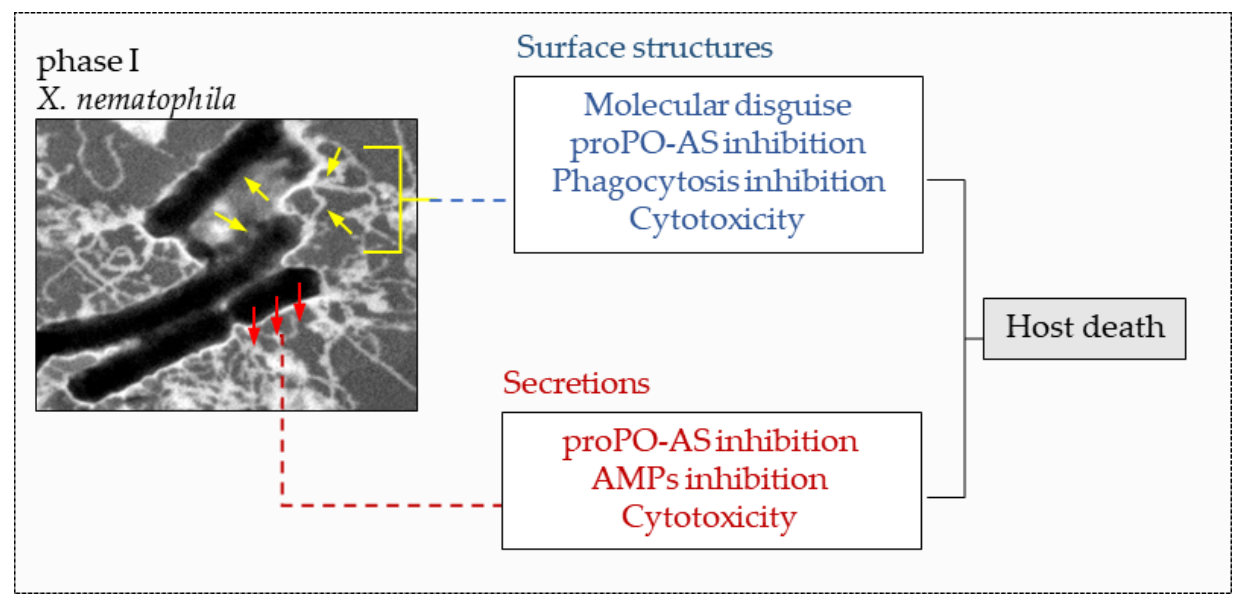

Figure 20. Immune evasion/suppression and lethality of phase I Xenorhabdus bacteria are mediated by both surface structures and secretions. Inset: a TEM micrograph of negative-stained X. nematophila, white filaments (yellow arrows) are the surface structures of the microorganism in the virulent phase (phase I), (TEM image from [177]).

The level of pathogenicity of X. nematophila and X. bovienii seem to be different, as when these bacteria are experimentally injected without their nematode, $X$. bovienii shows a lower virulence with respect to X. nematophila [195]; moreover, differences in genome regions (or genes) may contribute to the variable virulence of X. bovienii strains [196]. Entomopathogenic bacteria use a wide range of mechanisms to secrete proteins involved in virulence, to acquire nutrient, and to compete with other bacteria, examining secretion mechanisms and the structure and functions of secreted compounds, could also help to understand pathogens evolution [197]. Regarding the pool of secretions and structures of symbionts, it is interesting to note that even within the same species, among different strains, there are differences in the bioactive molecular pool, and this seems to be related to the infected insect species. These intraspecific differences seem to be induced by the environment in which the bacterium is found, thus it depends on its parasitized insect target, some secreted hemolysins, such as PhlA and XhlA [198,199] although homologs, may play different roles in pathogeny, suggesting the adaptation of pathogens to different niches [197]. This behavior allowed researchers to coin the term ecotype, and bacterial ecotypes are defined as evolutionarily and ecologically distinct groups [200]. The use of this definition could help researchers to better define and characterize some species strains that produce particular molecules when interacting with a specific host. Moreover, variation in the ability of the bacterial strains to establish a symbiosis with their nematode could result from a coevolution/adaptation process [201].

\section{Concluding Remarks}

Although there is still much to learn about EPN biology, the literature on S. feltiae and S. carpocapsae is extensive and from its analysis some differences are evident in terms of the efficiency and strategies used by these parasites towards their hosts.

S. carpocapsae shows a higher index of lethality, especially when used at higher ambient temperatures, while $S$. feltiae seems to work better at lower temperatures. The biological processes triggered by $S$. carpocapsae (nematode alone), in the early stages of infection, seem not to have a drastic effect on the host immune response; the parasite cuticle is limited to a role of immune evasion and no phenomena of immune suppression have been observed; otherwise, S. carpocapsae secretions cause a severe alteration of the host physiology. In contrast, S. feltiae, shortly after penetration, induces both immuno-evasive and immuno-suppressive phenomena, these processes seem to be independent of the nematode secretions and they involve the nematode body surface. 
The body surface of $S$. feltiae is capable of specific interactions with some molecular receptors (PRRs) present in the hemolymph of the host, which play a key role in the triggering of various immune processes. In fact, their removal results in a profound immunodeficiency in the target insect.

These different strategies of the two nematodes may be linked to the level of toxicity of their symbiotic bacteria; from studies carried out on isolated symbionts, it is clear that X. nematophila seems to be more aggressive, with a virulent phase more lethal than $X$. bovienii. Thus, it seems that in these models, there is a balance between the two organisms that constitutes the nematocomplex; a less aggressive nematode carries a more virulent bacterium, and vice versa. However, this balance between the nematode and its symbionts makes either S. feltiae/X. bovienii or S. carpocapsae /X. nematophila complexes good candidates for biocontrol purposes.

Although many studies have proposed exhaustive analyses of the efficacy of the EPNs in the field, or in the laboratory, to date the molecular mechanisms, parasite evasion strategies and immune processes that are modulated by the presence of entomopathogenic complexes, have not been completely clarified. There are many reasons that justify inconsistencies in the data: a restricted experimental approach aimed to investigate one or few physiological processes, the choice to study the nematode alone or the isolated symbiotic bacteria and finally the variability of responses observed in different hosts.

Future perspectives of this research area are surely of great interest and could furnish valuable information on evolutionary processes that gave rise to the current interactions among organisms, such as symbiosis and parasitism. Relationships which are established among nematodes, symbiotic bacteria and their host insects range from behavioral adaptations to modulations of host physiology in a complex tripartite biological model. In addition, the investigation of these processes, by means of a multidisciplinary approach, is extremely useful, both from the point of view of basic science and from an applicative perspective, with the aim to control insect species that are potentially dangerous either to the environment or to animal and human health.

Author Contributions: Both Authors participated in the writing of this review.

Funding: Both this research and APC were funded by University of Insubria, FAR grant/2017.

Acknowledgments: We want to dedicate this work to Manuela Pagani because she inspired our research many years ago and to Anthony Nappi, he was not just a teacher, but also a dear friend.

Conflicts of Interest: The authors declare no conflict of interest.

\section{References}

1. Blaxter, M.L. Nematoda: Genes, genomes and the evolution of parasitism. Adv. Parasitol. 2003, 54, 101-195. [PubMed]

2. Blaxter, M.; De Ley, P.; Garey, J.; Liu, L.; Scheldeman, P.; Vierstraete, A.; Vanfleteren, J.; Mackey, L.; Dorris, M.; Frisse, L. A molecular evolutionary framework for the phylum Nematoda. Nature 1998, 392, 71-75. [CrossRef] [PubMed]

3. Schmid-Hempel, P. Parasite immune evasion: A momentous molecular war. Trends Ecol. Evol. 2008, 23, 318-326. [CrossRef] [PubMed]

4. Gaugler, R.; Kaya, H.K. (Eds.) Entomopathogenic Nematodes in Biological Control; CRC Press: Boca Raton, FL, USA, 1990.

5. Georgis, R.; Manweiler, S.A. Entomopathogenic nematodes: A developing biological control technology. Agric. Zool. Rev. 1994, 6, 63-94.

6. Poinar, G. Nematode biopesticides Fundam. Appl. Nematol. 1998, 21, 733-737.

7. Poinar, G.O., Jr. Origins and phylogenetic relationships of the entomophilic rhabditids Heterorhabditis and Steinernema. Fundam. Appl. Nematol. 1993, 16, 333-338.

8. Peters, A. The Natural Host Range of Steinernema and Heterorhabditis spp. and Their Impact on Insect Populations. Biocontrol. Sci. Technol. 1996, 6, 389-402. [CrossRef]

9. Campbell, J.F.; Lewis, E.E.; Stock, S.P.; Nadler, S.; Kaya, H.K. Evolution of host search strategies in entomopathogenic nematodes. J. Nematol. 2003, 35, 142-145. [PubMed] 
10. Baiocchi, T.; Lee, G.; Choe, D.H.; Dillman, A.R. Host seeking parasitic nematodes use specific odors to assess host resources. Sci. Rep. 2017, 7, 6270. [CrossRef] [PubMed]

11. Stock, S.P.; Chaerani, G.; Rani, T. Morphological and molecular characterisation of Steinernema hermaphroditumn. sp. (Nematoda: Steinernematidae), an entomopathogenic nematode from Indonesia, and its phylogenetic relationships with other members of the genus. Nematology 2004, 6, 401-412. [CrossRef]

12. Chaudhuri, J.; Kache, V.; Pires-daSilva, A. Regulation of sexual plasticity in a nematode that produces males, females, and hermaphrodites. Curr. Biol. 2011, 21, 1548-1551. [CrossRef] [PubMed]

13. Poinar, G.O., Jr. Nematodes for Biological Control of Insects; CRC Press: Boca Raton, FL, USA, 1979.

14. Kaya, H.K.; Gaugler, R. Entomopathogenic nematodes. Annu. Rev. Entomol. 1993, 38, 181-206. [CrossRef]

15. Forst, S.; Nealson, K. Molecular biology of the symbiotic-pathogenic bacteria Xenorhabdus spp. \& Photorhabdus spp. Microbiol. Rev. 1996, 60, 21-43. [PubMed]

16. Forst, S.; Dowds, B.; Boemare, N.; Stackebrandt, E. Xenorhabdus and Photorhabdus spp.: Bugs that kill bugs. Annu. Rev. Microbiol. 1997, 51, 47-72. [CrossRef] [PubMed]

17. Forst, S.; Clarke, D. Bacteria-nematode symbiosis. In Entomopathogenic Nematology; Gaugler, R., Ed.; CAB International: London, UK, 2001; pp. 57-77.

18. Silva, C.P.; Waterfield, N.R.; Daborn, P.J.; Dean, P.; Chilver, T.; Au, C.P.; Sharma, S.; Potter, U.; Reynolds, S.E.; Ffrench-Constant, R.H. Bacterial infection of a model insect: Photorhabdus luminescens and Manduca sexta. Cell. Microbiol. 2002, 4, 329-339. [CrossRef] [PubMed]

19. Poinar, G.O.; Grewal, P.S. History of entomopathogenic nematology. J. Nematol. 2012, 44, 153-161. [PubMed]

20. Babic, I.; Fischer-Saux, M.; Giraud, E.; Boemare, N. Occurrence of natural dixenic associations between the symbiont Photorhabdus luminescens and bacteria related to Ochrobactrum spp. in tropical entomopathogenic Heterorhabditis spp. (Nematoda, Rhabditida). Microbiology 2000, 146, 709-718. [CrossRef] [PubMed]

21. Lysenko, O.B.; Weiser, J. Bacteria associated with the nematode Neoplectana carpocapsae and the pathogenicity of this complex for Galleria mellonella larvae. J. Invertebr. Pathol. 1974, 24, 332-336. [CrossRef]

22. Enright, M.R.; Griffin, C.T. Specificity of association between Paenibacillus spp. and the entomopathogenic nematodes, Heterorhabditis spp. Microb. Ecol. 2004, 48, 414-423. [CrossRef] [PubMed]

23. Kim, Y.; Kim, K.; Seo, J.; Shrestha, S.; Kim, H.H.; Nalini, M.; Yi, Y. Identification of an entomopathogenic bacterium, Serratia sp. ANU101, and its hemolytic activity. J. Microbiol. Biotechnol. 2009, 19, 314-322. [CrossRef] [PubMed]

24. Dillman, A.R.; Chaston, J.M.; Adams, B.J.; Ciche, T.A.; Goodrich-Blair, H.; Stock, S.P.; Sternberg, P.W. An entomopathogenic nematode by any other name. PLoS Pathog. 2012, 8, e1002527. [CrossRef] [PubMed]

25. Mandel, M.J. Models and approaches to dissect host-symbiont specificity. Trends Microbiol. 2010, 18, 504-511. [CrossRef] [PubMed]

26. Dunphy, G.; Thurston, G. Insect immunity. In Entomopathogenic Nematodes in Biological Control; Gaugler, R., Kaya, H.K., Eds.; CRC Press: Boca Raton, FL, USA, 1990; pp. 301-326.

27. Eleftherianos, I.; Yadav, S.; Kenney, E.; Cooper, D.; Ozakman, Y.; Patrnogic, J. Role of Endosymbionts in Insect-Parasitic Nematode Interactions. Trends Parasitol. 2018, 34, 430-444. [CrossRef] [PubMed]

28. Schmid-Hempel, P. Immune defence, parasite evasion strategies and their relevance for macroscopic phenomena such as virulence. Philos. Trans. R. Soc. Lond. B Biol. Sci. 2009, 364, 85-98. [CrossRef] [PubMed]

29. Ligoxygakis, P. Advances in Insect Physiology, Insect Immunity; Academic Press: Cambridge, MA, USA, 2017; Volume 52, ISBN 9780128117750.

30. Hoffmann, J.A.; Reichhart, J.M.; Hetru, C. Innate immunity in higher insects. Curr. Opin. Immunol. 1996, 8, 8-13. [CrossRef]

31. Chambers, M.C.; Schneider, D.S. Pioneering immunology: Insect style. Curr. Opin. Immunol. 2012, $24,10-14$. [CrossRef] [PubMed]

32. Loker, E.S. On being a parasite in an invertebrate host: A short survival course. J. Parasitol. 1994, 80, 728-747. [CrossRef] [PubMed]

33. Schmid-Hempel, P. Natural insect host-parasite systems show immune priming and specificity: Puzzles to be solved. Bioessays 2005, 27, 1026-1034. [CrossRef] [PubMed]

34. Medzhitov, R. Toll-like receptors and innate immunity. Nat. Rev. Immunol. 2001, 1, 135-145. [CrossRef] [PubMed] 
35. Medzhitov, R.; Janeway, C.A., Jr. Decoding the patterns of self and nonself by the innate immune system. Science 2002, 296, 298-300. [CrossRef] [PubMed]

36. Kanost, M.R.; Jiang, H.; Qiang, Y.X. Innate immune responses of a lepidopteran insect, Manduca sexta. Immunol. Rev. 2004, 198, 97-105. [CrossRef] [PubMed]

37. Jiang, H.; Vilcinskas, A.; Kanost, M.R. Immunity in lepidopteran insects. Adv. Exp. Med. Biol. 2010, 708, 181-204. [PubMed]

38. Janeway, C.A.; Medzhitov, R. Innate Immune Recognition. Annu. Rev. Immunol. 2002, 20, 197-216. [CrossRef] [PubMed]

39. Akira, S.; Uematsu, S.; Takeuchi, O. Pathogen recognition and innate immunity. Cell 2006, 124, $783-801$. [CrossRef] [PubMed]

40. Raetz, C.R.; Whitfield, C. Lipopolysaccharide endotoxins. Annu. Rev. Biochem. 2002, 71, 635-700. [CrossRef] [PubMed]

41. Trent, M.S.; Stead, C.M.; Tran, A.X.; Hankins, J.V. Diversity of endotoxin and its impact on pathogenesis. J. Endotoxin Res. 2006, 12, 205-223. [CrossRef] [PubMed]

42. Johannsen, L. Biological properties of bacterial peptidoglycan. APMIS 1993, 101, 337-344. [CrossRef] [PubMed]

43. Goodridge, H.S.; Wolf, A.J.; Underhill, D.M. Beta-glucan recognition by the innate immune system. Immunol. Rev. 2009, 230, 38-50. [CrossRef] [PubMed]

44. Morath, S.; von Aulock, S.; Hartung, T. Structure/function relationships of lipoteichoic acids. J. Endotoxin Res. 2005, 11, 348-356. [CrossRef] [PubMed]

45. Samatey, F.A.; Imada, K.; Nagashima, S.; Vonderviszt, F.; Kumasaka, T.; Yamamoto, M.; Namba, K. Structure of the bacterial flagellar protofilament and implications for a switch for supercoiling. Nature 2001, 410, 331-337. [CrossRef] [PubMed]

46. Takeuchi, O.; Akira, S. Innate immunity to virus infection. Immunol. Rev. 2009, 227, 75-86. [CrossRef] [PubMed]

47. Krieg, A.M. CpG motifs in bacterial DNA and their immune effects. Annu. Rev. Immunol. 2002, 20, 709-760. [CrossRef] [PubMed]

48. Hoffmann, J.A.; Kafatos, F.C.; Janeway, C.A.; Ezekowitz, R.A. Phylogenetic perspectives in innate immunity. Science 1999, 284, 1313-1318. [CrossRef] [PubMed]

49. Dimopoulos, G. Insect immunity and its implication in mosquito-malaria interactions. Cell. Microbiol. 2003, 5, 3-14. [CrossRef] [PubMed]

50. Stokes, B.A.; Yadav, S.; Shokal, U.; Smith, L.C.; Eleftherianos, I. Bacterial and fungal pattern recognition receptors in homologous innate signaling pathways of insects and mammals. Front. Microbiol. 2015, 6, 19. [CrossRef] [PubMed]

51. Yoshida, H.K.; Kinoshita, K.; Ashida, M. Purification of a peptidoglycan recognition protein from hemolymph of the silkworm, Bombyx mori. J. Biol. Chem. 1996, 271, 13854-13860. [CrossRef] [PubMed]

52. Royet, J.; Dziarski, R. Peptidoglycan recognition proteins: Pleiotropic sensors and effectors of antimicrobial defences. Nat. Rev. Microbiol. 2007, 5, 264-277. [CrossRef] [PubMed]

53. Yu, X.Q.; Zhu, Y.; Ma, C.; Fabrick, J.A.; Kanost, M.R. Pattern recognition proteins in Manduca sexta plasma. Insect Biochem. Mol. Biol. 2002, 32, 1287-1293. [CrossRef]

54. Zhu, Y.; Johnson, T.J.; Myers, A.A.; Kanost, M.R. Identification by subtractive suppression hybridization of bacteria-induced genes expressed in Manduca sexta fat body. Insect Biochem. Mol. Biol. 2003, 33, 541-559. [CrossRef]

55. Ma, C.; Kanost, M.R. A $\beta 1,3-g l u c a n$ recognition protein from an insect, Manduca sexta, agglutinates microorganisms and activates the phenoloxidase cascade. J. Biol. Chem. 2000, 275, 7505-7514. [CrossRef] [PubMed]

56. Weis, W.I.; Taylor, M.E.; Drickamer, K. The C-type lectin superfamily in the immune system. Immunol. Rev. 1998, 163, 19-34. [CrossRef] [PubMed]

57. Vasta, G.R.; Quesenberry, M.; Ahmed, H.; O'Leary, N. C-type lectins and galectins mediate innate and adaptive immune functions: Their roles in the complement activation pathway. Dev. Comp. Immunol. 1999, 23, 401-420. [CrossRef]

58. Yu, X.Q.; Kanost, M.R. Manduca sexta lipopolysaccharide-specific immulectin-2 protects larvae from bacterial infection. Dev. Comp. Immunol. 2003, 27, 189-196. [CrossRef] 
59. Yu, X.Q.; Kanost, M.R. Immulectin-2, a pattern recognition receptor that stimulates hemocytes encapsulation and melanization in the tobacco hornworm, Manduca sexta. Dev. Comp. Immunol. 2004, 28, 891-900. [CrossRef] [PubMed]

60. Dunphy, G.; Halwani, A. Haemolymph proteins of larvae of Galleria mellonella detoxify endotoxins of the insect pathogenic bacteria Xenorhabdus nematophilus (Enterobacteriaceae). J. Insect Physiol. 1997, 43, 1023-1029. [CrossRef]

61. Wiesner, A.; Losen, S.; Kopacek, P.; Weise, C.; Götz, P. Isolated apolipophorin III from Galleria mellonella stimulates the immune reactions of the insect. J. Insect Physiol. 1997, 43, 383-391. [CrossRef]

62. Niere, M.; Meisslitzer, C.; Dettloff, M.; Weise, C.; Ziegler, M.; Wiesner, A. Insect immune activation by recombinant Galleria mellonella apolipophorin III. Biochem. Biophys. Acta 1999, 1433, 16-26. [CrossRef]

63. Zdybicka-Barabas, A.; Januszanis, B.; Mak, P.; Cytryńska, M. An atomic force microscopy study of Galleria mellonella apolipophorin III effect on bacteria. Biochim. Biophys. Acta 2011, 1808, 1896-1906. [CrossRef] [PubMed]

64. Zdybicka-Barabas, A.; Mak, P.; Klys, A.; Skrzypiec, K.; Mendyk, E.; Fiołka, M.; Cytryńska, M. Synergistic action of Galleria mellonella anionic peptide 2 and lysozyme against Gram-negative bacteria. Biochim. Biophys. Acta 2012, 1818, 2623-2635. [CrossRef] [PubMed]

65. Marmaras, V.J.; Lampropoulou, M. Regulators and signalling in insect haemocyte immunity. Cell. Signal. 2009, 21, 186-195. [CrossRef] [PubMed]

66. Hultmark, D. Drosophila immunity: Paths and patterns. Curr. Opin. Immunol. 2003, 15, 12-19. [CrossRef]

67. Schmidt, O.; Theopold, U.; Strand, M.R. Innate immunity and its evasion and suppression by hymenopteran endoparasitoids. Bioessays 2001, 23, 344-351. [CrossRef] [PubMed]

68. Dubovskiy, I.M.; Kryukova, N.A.; Glupov, V.V.; Ratcliffe, N.A. Encapsulation and nodulation in insects. Invertebr. Surv. J. 2016, 13, 229-246.

69. Kocks, C.; Cho, J.H.; Nehme, N.; Ulvila, J.; Pearson, A.M.; Meister, M.; Strom, C.; Conto, S.L.; Hetru, C.; Stuart, L.M.; et al. Eater, a transmembrane protein mediating phagocytosis of bacterial pathogens in Drosophila. Cell 2005, 23, 335-346. [CrossRef] [PubMed]

70. Hoffmann, J.A. The immune response of Drosophila. Nature 2003, 426, 33-38. [CrossRef] [PubMed]

71. De Gregorio, E.; Spellman, P.T.; Tzou, P.; Rubin, G.M.; Lemaitre, B. The Toll and Imd pathways are the major regulators of the immune response in Drosophila. EMBO J. 2002, 21, 2568-2579. [CrossRef] [PubMed]

72. Hoffmann, J.A.; Reichhart, J.M. Drosophila innate immunity: An evolutionary perspective. Nat. Immunol. 2002, 3, 121-126. [CrossRef] [PubMed]

73. Leulier, F.; Parquet, C.; Pili-Floury, S.; Ryu, J.H.; Caroff, M.; Lee, W.J.; Mengin-Lecreulx, D.; Lemaitre, B. The Drosophila immune system detects bacteria through specific peptidoglycan recognition. Nat. Immunol. 2003, 4, 478-484. [CrossRef] [PubMed]

74. Kurata, S. Extracellular and intracellular pathogen recognition by Drosophila PGRP-LE and PGRP-LC. Int. Immunol. 2010, 22, 143-148. [CrossRef] [PubMed]

75. Georgel, P.; Naitza, S.; Kappler, C.; Ferrandon, D.; Zachary, D.; Swimmer, C.; Kopczynski, C.; Duyk, G.; Reichhart, J.M.; Hoffmann, J.A. Drosophila immune deficiency (IMD) is a death domain protein that activates antibacterial defense and can promote apoptosis. Dev. Cell 2001, 4, 503-514. [CrossRef]

76. Dziarski, R. Peptidoglycan recognition proteins (PGRPs). Mol. Immunol. 2004, 40, 877-886. [CrossRef] [PubMed]

77. Choe, K.M.; Lee, H.; Anderson, K.V. Drosophila peptidoglycan recognition protein LC (PGRP-LC) acts as a signal-transducing innate immune receptor. Proc. Natl. Acad. Sci. USA 2005, 102, 1122-1126. [CrossRef] [PubMed]

78. Tzou, P.; De Gregorio, E.; Lemaitre, B. How Drosophila combats microbial infection: A model to study innate immunity and host-pathogen interactions. Curr. Opin. Microbiol. 2002, 5, 102-110. [CrossRef]

79. Tanji, T.; Ip, Y.T. Regulators of the Toll and Imd pathways in the Drosophila innate immune response. Trends Immunol. 2005, 26, 193-198. [CrossRef] [PubMed]

80. Tanji, T.; Hu, X.; Weber, A.N.; Ip, Y.T. Toll and IMD pathways synergistically activate an innate immune response in Drosophila melanogaster. Mol. Cell. Biol. 2007, 27, 4578-4588. [CrossRef] [PubMed]

81. Aggarwal, K.; Silverman, N. Positive and negative regulation of the Drosophila immune response. BMB Rep. 2008, 41, 267-277. [CrossRef] [PubMed] 
82. Sun, S.C.; Åsling, B.; Faye, I. Organization and expression of the immunoresponsive lysozyme gene in a giant silk moth, Hyalophora cecropia. J. Biol. Chem. 1991, 266, 6644-6649. [PubMed]

83. Hetru, C.; Hoffmann, J.A. NF-kappaB in the immune response of Drosophila. Cold Spring Harb. Perspect. Biol. 2009, 1, a000232. [CrossRef] [PubMed]

84. Cherry, S.; Silverman, N. Host-pathogen interactions in Drosophila: New tricks from an old friend. Nat. Immunol. 2006, 7, 911-917. [CrossRef] [PubMed]

85. Vey, A. Humoral Encapsulation. In Insect Immunity; Pathak, J.P.N., Ed.; Series Entomologica; Springer: Dordrecht, The Netherlands, 1993; p. 48. [CrossRef]

86. Brivio's Lab; Laboratory of Comparative Immunology and Parasitology, Department of Theoretical and Applied Sciences, University of Insubria, Varese, Italy. Personal communication, 2018.

87. Cerenius, L.; Lee, B.L.; Söderhäll, K. The proPO-system: Pros and cons for its role in invertebrate immunity. Trends Immunol. 2008, 29, 263-271. [CrossRef] [PubMed]

88. Nappi, A.J.; Kohler, L.; Mastore, M. Signaling pathways implicated in the cellular innate immune responses of Drosophila. Invertebr. Surv. J. 2004, 1, 5-33.

89. Ashida, M. The prophenoloxidase cascade in insect immunity. Res. Immunol. 1990, 90, 908-910. [CrossRef]

90. Brivio, M.F.; Mazzei, C.; Scarì, G. proPO System of Allogamus auricollis (Insecta): Effects of Various Compounds on Phenoloxidase Activity. Comp. Biochem. Physiol. B 1996, 113, 281-287. [CrossRef]

91. Dimopoulous, G.; Müller, H.M.; Levashina, E.A.; Kafatos, F.C. Innate immune defense against malaria infection in the mosquito. Curr. Opin. Immunol. 2001, 13, 79-88. [CrossRef]

92. Jomori, T.; Natori, S. Function of the lipopolysaccharide-binding protein of Periplaneta americana as an opsonin. FEBS Lett. 1992, 296, 283-286. [CrossRef]

93. Söderhäll, K. Invertebrate immunity. Dev. Comp. Immunol. 1999, 23, 263-266. [PubMed]

94. Bulet, P.; Stöcklin, R. Insect antimicrobial peptides: Structures, properties and gene regulation. Protein Pept. Lett. 2005, 12, 3-11. [CrossRef] [PubMed]

95. Hull, R.; Katete, R.; Ntwasa, M. Therapeutic potential of antimicrobial peptides from insects. Biotechnol. Mol. Biol. Rev. 2012, 7, 31-47.

96. Yeung, A.T.; Gellatly, S.L.; HancocK, R.E. Multifunctional cationic host defence peptides and their clinical applications. Cell. Mol. Life Sci. 2011, 68, 2161-2176. [CrossRef] [PubMed]

97. Bulet, P.; Stöcklin, R.; Menin, L. Anti-microbial peptides: From invertebrates to vertebrates. Immunol. Rev. 2004, 198, 169-184. [CrossRef] [PubMed]

98. Hultmark, D. Insect lysozymes. EXS 1996, 75, 87-102. [PubMed]

99. Brivio, M.F.; Moro, M.; Mastore, M. Down-regulation of antibacterial peptide synthesis in an insect model induced by the body-surface of an entomoparasite (Steinernema feltiae). Dev. Comp. Immunol. 2006, 30, 627-638. [CrossRef] [PubMed]

100. Strand, M.R. The insect cellular immune response. Insect Sci. 2008, 15, 1-14. [CrossRef]

101. Bulet, P.; Hetru, C.; Dimarcq, J.L.; Hoffmann, D. Antimicrobial peptides in insects; structure and function. Dev. Comp. Immunol. 1999, 23, 329-344. [CrossRef]

102. Dubovskiy, I.M.; Grizanova, E.V.; Whitten, M.M.; Mukherjee, K.; Greig, C.; Alikina, T.; Kabilov, M.; Vilcinskas, A.; Glupov, V.V.; Butt, T.M. Immuno-physiological adaptations confer wax moth Galleria mellonella resistance to Bacillus thuringiensis. Virulence 2016, 7, 860-870. [CrossRef] [PubMed]

103. Gupta, A.P.; Kerkut, G.A.; Gilbert, L.I. (Eds.) Comprehensive Insect Physiology, Biochemistry, and Pharmacology; Pergamon Press: Oxford, UK, 1985; Volume 3.

104. Brehélin, M.; Zachary, D. Insect haemocytes: A new classification to rule out the controversy. In Immunity in Invertebrates; Brehélin, M., Ed.; Springer: Berlin, Germany, 1986; pp. 36-48.

105. Vilmos, P.; Nagy, I.; Kurucz, E.; Hultmark, D.; Gateff, E.; Andó, I. A rapid rosetting method for separation of hemocyte sub-populations of Drosophila melanogaster. Dev. Comp. Immunol. 2004, 28, 555-563. [CrossRef] [PubMed]

106. Willott, E.; Trenczek, T.; Thrower, L.W.; Kanost, M.R. Immunochemical identification of insect hemocyte populations: Monoclonal antibodies distinguish four major hemocyte types in Manduca sexta. Eur. J. Cell Biol. 1994, 65, 417-423. [PubMed]

107. Strand, M.R.; Johnson, J.A. Characterization of monoclonal antibodies to hemocytes of Pseudoplusia includens. J. Insect Physiol. 1996, 42, 21-31. [CrossRef] 
108. Gardiner, E.M.M.; Strand, M.R. Monoclonal antibodies bind distinct classes of hemocytes in the moth Pseudoplusia includens. J. Insect Physiol. 1999, 45, 113-126. [CrossRef]

109. Lebestky, T.; Chang, T.; Hartenstein, V.; Banerjee, U. Specification of Drosophila hematopoietic lineage by conserved transcription factors. Science 2000, 288, 146-149. [CrossRef] [PubMed]

110. Wood, W.; Jacinto, A. Drosophila melanogaster embryonic haemocytes: Masters of multitasking. Nat. Rev. Mol. Cell Biol. 2007, 8, 542-551. [CrossRef] [PubMed]

111. Ratcliffe, N.A.; Rowley, A.F.; Fitzgerald, S.W. Invertebrate immunity: Basic concepts and recent advances. Int. Rev. Cytol. 1985, 97, 183-349.

112. Tepass, U.; Fessler, L.I.; Aziz, A.; Hartenstein, V. Embryonic origin of hemocytes and their relationship to cell death in Drosophila. Development 1994, 120, 1829-1837. [PubMed]

113. Lavine, M.D.; Strand, M.R. Insect hemocytes and their role in immunity. Insect Biochem. Mol. Biol. 2002, 32, 1295-1309. [CrossRef]

114. Sass, M.; Kiss, A.; Locke, M. Integument and hemocyte peptides. J. Insect Physiol. 1994, 40, 407-421. [CrossRef]

115. Stuart, L.M.; Ezekowitz, R.A. Phagocytosis and comparative innate immunity: Learning on the fly. Nat. Rev. Immunol. 2008, 8, 131-141. [CrossRef] [PubMed]

116. Tojo, S.; Naganuma, F.; Arakawa, K.; Yokoo, S. Involvement of both granular cells and plasmatocytes in phagocytic reactions in the greater wax moth, Galleria mellonella. J. Insect Physiol. 2000, 46, 1129-1135. [CrossRef]

117. Rittig, M.G.; Kuhn, K.H.; Dechant, C.A.; Gauckler, A.; Modolell, M.; Ricciardi-Castagnoli, P.; Krause, A.; Burmester, G.R. Phagocytes from both vertebrate and invertebrate species use pooling-phagocytosis. Dev. Comp. Immunol. 1996, 20, 393-406. [CrossRef]

118. Ni, Y.; Tizard, I. Lectin-carbohydrate interactions in the immune system. Vet. Immunol. Immunopathol. 1996, 55, 205-223. [CrossRef]

119. Wang, Y.; Jiang, H. Prophenoloxidase (PPO) activation in Manduca sexta: An initial analysis of molecular interactions among PPO, PPO-activating proteinase-3 (PAP-3), and a cofactor. Insect Biochem. Mol. Biol. 2004, 34, 731-742. [CrossRef] [PubMed]

120. Marmaras, V.J.; Charalambidis, N.D. Certain hemocyte proteins of the Medfly, Ceratitis capitata, are responsible for nonself recognition and immobilization of Escherichia coii in vitro. Arch. Insect Biochem. Physiol. 1992, 21, 281-288. [CrossRef]

121. Mastore, M.; Brivio, M.F. Cuticular surface lipids are responsible for disguise properties of an entomoparasite against host cellular responses. Dev. Comp. Immunol. 2008, 32, 1050-1062. [CrossRef] [PubMed]

122. Clark, K.D.; Volkman, B.F.; Thoetkiattiku, H.; Hayakawa, Y.; Strand, M.R. N-terminal residues of plasmatocyte spreading peptide possess specific determinants required for biological activity. J. Biol. Chem. 2001, 276, 37431-37435. [CrossRef] [PubMed]

123. Clark, K.D.; Volkman, B.F.; Thoetkiattikul, H.; King, D.; Hayakawa, Y.; Strand, M.R. Alanine-scanning Mutagenesis of Plasmatocyte Spreading Peptide Identifies Critical Residues for Biological Activity. J. Biol. Chem. 2001, 276, 18491-18496. [CrossRef] [PubMed]

124. Srikanth, K.; Park, J.; Stanley, D.W.; Kim, Y. Plasmatocyte-spreading peptide influences hemocyte behavior via eicosanoids. Arch. Insect Biochem. Physiol. 2011, 78, 145-160. [CrossRef] [PubMed]

125. Salt, G. Teratocytes as a means of resistance to cellular defense reactions. Nature 1971, 232, 639. [CrossRef] [PubMed]

126. Gillespie, J.P.; Kanost, M.R.; Trenczek, T. Biological mediators of insect immunity. Annu. Rev. Entomol. 1997, 42, 611-614. [CrossRef] [PubMed]

127. Vass, E.; Nappi, A.J. Developmental and immunological aspects of Drosophila-parasitoid relationships. J. Parasitol. 2000, 86, 1259-1270. [CrossRef] [PubMed]

128. Nappi, A.J.; Vass, E. Cytotoxic reactions associated with insect immunity. Adv. Exp. Med. Biol. 2001, 484, 329-348. [PubMed]

129. Griffin, C.T. Perspectives on the Behavior of Entomopathogenic Nematodes from Dispersal to Reproduction: Traits Contributing to Nematode Fitness and Biocontrol Efficacy. J. Nematol. 2012, 44, 177-184. [PubMed]

130. Castillo, J.C.; Shokal, U.; Eleftherianos, I. A novel method for infecting Drosophila adult flies with insect pathogenic nematodes. Virulence 2012, 3, 339-347. [CrossRef] [PubMed] 
131. Peña, J.M.; Carrillo, M.A.; Hallem, E.A. Variation in the susceptibility of Drosophila to different entomopathogenic nematodes. Infect. Immun. 2015, 83, 1130-1138. [CrossRef] [PubMed]

132. Bayne, C.J.; Boswell, C.A.; Yui, M.A. Widespread antigenic cross-reactivity between plasma proteins of a gastropod, and its trematode parasite. Dev. Comp. Immunol. 1987, 11, 321-329. [CrossRef]

133. Damian, R.T. Tropomyosin and molecular mimicry. Parasitol. Today 1991, 7, 96. [CrossRef]

134. Weston, D.; Allen, B.; Thakur, A.; LoVerde, P.T.; Kemp, W.M. Invertebrate host-parasite relationships: Convergent evolution of a tropomyosin epitope between Schistosoma sp., Fasciola hepatica, and certain pulmonate snails. Exp. Parasitol. 1994, 78, 269-278. [CrossRef] [PubMed]

135. Strand, M.R.; Pech, L.L. Immunological basis for compatibility in parasitoid-host relationships. Annu. Rev. Entomol. 1995, 40, 31-56. [CrossRef] [PubMed]

136. Kathirithamby, J.; Ross, L.D.; Johnston, J.S. Masquerading as self? Endoparasitic Strepsiptera (Insecta) enclose themselves in host-derived epidermal bag. Proc. Natl. Acad. Sci. USA 2003, 100, 7655-7659. [CrossRef] [PubMed]

137. Simões, N.; Rosa, J.S. Pathogenicity and host specificity of entomopathogenic nematodes. Biocontrol Sci. Technol. 1996, 6, 403-411. [CrossRef]

138. Balasubramanian, N.; Hao, Y.J.; Toubarro, D.; Nascimento, G.; Simões, N. Purification, biochemical and molecular analysis of a chymotrypsin protease with prophenoloxidase suppression activity from the entomopathogenic nematode Steinernema carpocapsae. Int. J. Parasitol. 2009, 39, 975-984. [CrossRef] [PubMed]

139. Politz, S.M.; Philipp, M. Caenorhabditis elegans as a model for parasitic nematodes: A focus on the cuticle. Parasitol. Today 1992, 8, 6-12. [CrossRef]

140. Akhurst, R.J.; Dunphy, G.B. Tripartite interactions between symbiotically associated entomopathogenic bacteria, nematodes, and their insect hosts. In Parasites and Pathogens of Insects; Academic Press: Cambridge, MA, USA, 1993; Volume 2, pp. 1-23.

141. Blaxter, M.L.; Page, A.P.; Rudin, W.; Maizels, R.M. Nematode surface coats: actively evading immunity. Parasitol. Today 1992, 8, 243-247. [CrossRef]

142. Cox, G.N.; Kusch, M.; DeNevi, K.; Edgar, R.S. Temporal regulation of cuticle synthesis during development of Caenorhabditis elegans. Dev. Biol. 1981, 84, 277-285. [CrossRef]

143. Cox, G.N.; Kusch, M.; Edgar, R.S. Cuticle of Caenorhabditis elegans: Its isolation and partial characterisation. J. Cell Biol. 1981, 90, 7-17. [CrossRef] [PubMed]

144. Dunphy, G.; Webster, J. Partially characterized components of the epicuticle of dauer juvenile Steinernema feltiae and their influence on the hemocyte activity in Galleria mellonella. J. Parasitol. 1987, 73, 584-588. [CrossRef]

145. Brivio, M.F.; Pagani, M.; Restelli, S. Immune suppression of Galleria mellonella (Insecta, Lepidoptera) humoral defenses induced by Steinernema feltiae (Nematoda, Rhabditida): Involvement of the parasite cuticle. Exp. Parasitol. 2002, 101, 149-156. [CrossRef]

146. Brivio, M.F.; Mastore, M.; Moro, M. The role of Steinernema feltiae body-surface lipids in host-parasite immunological interactions. Mol. Biochem. Parasitol. 2004, 135, 111-121. [CrossRef] [PubMed]

147. Halwani, A.E.; Dunphy, G.B. Apolipophorin-III in Galleria mellonella potentiates hemolymph lytic activity. Dev. Comp. Immunol. 1999, 23, 563-570. [CrossRef]

148. Finnerty, C.M.; Karplus, P.A.; Granados, R.R. The insect immune protein scolexin is a novel serine proteinase homolog. Protein Sci. 1999, 8, 242-248. [CrossRef] [PubMed]

149. Ryan, R.O.; Van der Horst, D.J. Lipid transport bio-chemistry and its role in energy production. Annu. Rev. Entomol. 2000, 45, 233-260. [CrossRef] [PubMed]

150. Zakarian, R.J.; Dunphy, G.B.; Albert, P.J.; Rau, M.E. Apolipophorin-III affects the activity of the haemocytes of Galleria mellonella larvae. J. Insect Physiol. 2002, 48, 715-723. [CrossRef]

151. Rahatkhah, Z.; Karimi, J.; Ghadamyari, M.; Brivio, M. Immune defences of Agriotes lineatus larvae against entomopathogenic nematodes. BioControl 2015, 60, 641-653. [CrossRef]

152. Abdolmaleki, A.; Dastjerdi, H.R.; Tanha Maafi, Z.; Naseri, B. Cellular and humoral responses of Pieris brassicae to infection by Steinernema feltiae, its symbiont bacteria, and their metabolites. Nematology 2017, 19, 477-487. [CrossRef]

153. Ebrahimi, L.; Shiri, M.; Dunphy, G.B. Effect of entomopathogenic nematode, Steinernema feltiae, on survival and plasma phenoloxidase activity of Helicoverpa armigera $(\mathrm{Hb})$ (Lepidoptera: Noctuidae) in laboratory conditions. Egypt. J. Biol. Pest Control 2018, 28, 12. [CrossRef] 
154. Li, X.Y.; Cowles, R.S.; Cowles, E.A.; Gaugler, R.; Cox-Foster, D.L. Relationship between the successful infection by entomopathogenic nematodes and the host immune response. Int. J. Parasitol. 2007, 37, 365-374. [CrossRef] [PubMed]

155. Ebrahimi, L.; Niknam, G.; Dunphy, G.B. Hemocyte responses of the Colorado potato beetle, Leptinotarsa decemlineata, and the greater wax moth, Galleria mellonella, to the entomopathogenic nematodes, Steinernema feltiae and Heterorhabditis bacteriophora. J. Insect Sci. 2011, 11, 75. [CrossRef] [PubMed]

156. Peters, A.; Ehlers, R.U. Encapsulation of the entomopathogenic nematode Steinernema feltiae in Tipula oleracea. J. Invertebr. Pathol. 1997, 69, 218-222. [CrossRef] [PubMed]

157. Cruz, N.; Rosa, J.S.; Simões, N. Encapsulation response of 6th instar of Pseudaletia unipuncta (Lepidoptera: Noctuidae) to Steinernema carpocapsae (Nematoda: Steinernematidae). J. Invertebr. Pathol. 2001, 78, 272-274. [CrossRef] [PubMed]

158. Wang, Y.; Gaugler, R. Steinernema glaseri surface coat protein suppresses the immune response of Popillia japonica (Coleoptera: Scarabaeidae) larvae. Biol. Control 1999, 14, 45-50. [CrossRef]

159. Gotz, P.; Boman, A.; Boman, H.G. Interactions between insect immunity and an insect-pathogenic nematode with symbiotic bacteria. Proc. R. Soc. Lond. B Biol. Sci. 1981, 212, 333-350. [CrossRef]

160. Laumond, C.; Simões, N.; Boemare, N. Toxins of entomoparasitic nematodes. Pathogenicity of Steinernema carpocapsae-prospectives of genetic engineering. C. R. Acad. Agric. Fr. 1989, 75, 135-138.

161. Snyder, H.; Stock, S.P.; Kim, S.K.; Flores-Lara, Y.; Forst, S. New insights into the colonization and release processes of Xenorhabdus nematophila and the morphology and ultrastructure of the bacterial receptacle of its nematode host, Steinernema carpocapsae. Appl. Environ. Microbiol. 2007, 73, 5338-5346. [CrossRef] [PubMed]

162. Mastore, M.; Arizza, V.; Manachini, B.; Brivio, M.F. Modulation of immune responses of Rhynchophorus ferrugineus (Insecta: Coleoptera) induced by the entomopathogenic nematode Steinernema carpocapsae (Nematoda: Rhabditida). Insect Sci. 2015, 22, 748-760. [CrossRef] [PubMed]

163. Lu, D.; Macchietto, M.; Chang, D.; Barros, M.M.; Baldwin, J.; Mortazavi, A.; Dillman, A.R. Activated entomopathogenic nematode infective juveniles release lethal venom proteins. PLoS Pathog. 2017, 13, e1006302. [CrossRef] [PubMed]

164. Toubarro, D.; Lucena-Robles, M.; Nascimento, G.; Costa, G.; Montiel, R.; Coelho, A.V.; Simões, N. An apoptosis-inducing serine protease secreted by the entomopathogenic nematode Steinernema carpocapsae. Int. J. Parasitol. 2009, 39, 1319-1330. [CrossRef] [PubMed]

165. Toubarro, D.; Avila, M.M.; Montiel, R.; Simões, N.A. pathogenic nematode targets recognition protein to avoid insect defenses. PLoS ONE 2013, 8, e75691. [CrossRef] [PubMed]

166. Hao, Y.J.; Montiel, R.; Nascimento, G.; Toubarro, D.; Simoes, N. Identification and expression analysis of the Steinernema carpocapsae elastase-like serine protease gene during the parasitic stage. Exp. Parasitol. 2009, 122, 51-60. [CrossRef] [PubMed]

167. Hao, Y.J.; Montiel, R.; Abubucker, S.; Mitreva, M.; Simões, N. Transcripts analysis of the entomopathogenic nematode Steinernema carpocapsae induced in vitro with insect haemolymph. Mol. Biochem. Parasitol. 2010, 169, 79-86. [CrossRef] [PubMed]

168. Jing, Y.; Toubarro, D.; Hao, Y.; Simões, N. Cloning, characterisation and heterologous expression of an astacin metalloprotease, Sc-AST, from the entomoparasitic nematode Steinernema carpocapsae. Mol. Biochem. Parasitol. 2010, 174, 101-108. [CrossRef] [PubMed]

169. Hao, Y.J.; Montiel, R.; Nascimento, G.; Toubarro, D.; Simoes, N. Identification, characterization of functional candidate genes for host-parasite interactions in entomopathogenetic nematode Steinernema carpocapsae by suppressive subtractive hybridization. Parasitol. Res. 2008, 103, 671-683. [CrossRef] [PubMed]

170. Balasubramanian, N.; Toubarro, D.; Nascimento, G.; Ferreira, R.; Simões, N. Purification, molecular characterization and gene expression analysis of an aspartic protease (Sc-ASP113) from the nematode Steinernema carpocapsae during the parasitic stage. Mol. Biochem. Parasitol. 2012, 182, 37-44. [CrossRef] [PubMed]

171. Balasubramanian, N.; Nascimento, G.; Ferreira, R.; Martinez, M.; Simões, N. Pepsin-like aspartic protease (Sc-ASP155) cloning, molecular characterization and gene expression analysis in developmental stages of nematode Steinernema carpocapsae. Gene 2012, 500, 164-171. [CrossRef] [PubMed]

172. Balasubramanian, N.; Simões, N. Cloning and molecular analysis of the aspartic protease Sc-ASP110 gene transcript in Steinernema carpocapsae. Parasitology 2013, 140, 1158-1167. [CrossRef] [PubMed] 
173. Toubarro, D.; Avila, M.M.; Hao, Y.; Balasubramanian, N.; Jing, Y.; Montiel, R.; Faria, T.Q.; Brito, R.M.; Simões, N. A serpin released by an entomopathogen impairs clot formation in insect defense system. PLoS ONE 2013, 8, e69161. [CrossRef] [PubMed]

174. Yadav, S.; Frazer, J.; Banga, A.; Pruitt, K.; Harsh, S.; Jaenike, J.; Eleftherianos, I. Endosymbiont-based immunity in Drosophila melanogaster against parasitic nematode infection. PLoS ONE 2018, 13, e0192183. [CrossRef] [PubMed]

175. Yi, Y.; Wu, G.; Lv, J.; Li, M. Eicosanoids mediate Galleria mellonella immune response to hemocoel injection of entomopathogenic nematode cuticles. Parasitol. Res. 2016, 115, 597-608. [CrossRef] [PubMed]

176. Walter, T.N.; Dunphy, G.B.; Mandato, C.A. Steinernema carpocapsae DD136: Metabolites limit the non-self adhesion responses of haemocytes of two lepidopteran larvae, Galleria mellonella (F. Pyralidae) and Malacosoma disstria (F. Lasiocampidae). Exp. Parasitol. 2008, 120, 2161-2174. [CrossRef] [PubMed]

177. Brivio, M.F.; Toscano, A.; De Pasquale, S.M.; De Lerma Barbaro, A.; Giovannardi, S.; Finzi, G.; Mastore, M. Surface protein components from entomopathogenic nematodes and their symbiotic bacteria: Effects on immune responses of the greater wax moth, Galleria mellonella (Lepidoptera: Pyralidae). Pest Manag. Sci. 2018. [CrossRef] [PubMed]

178. Binda-Rossetti, S.; Mastore, M.; Protasoni, M.; Brivio, M.F. Effects of an entomopathogen nematode on the immune response of the insect pest red palm weevil: Focus on the host antimicrobial response. J. Invertebr. Pathol. 2016, 133, 110-119. [CrossRef] [PubMed]

179. Darsouei, R.; Karimi, J.; Ghadamyari, M.; Hosseini, M. Differential Change Patterns of Main Antimicrobial Peptide Genes during Infection of Entomopathogenic Nematodes and Their Symbiotic Bacteria. J. Parasitol. 2017, 103, 349-358. [CrossRef] [PubMed]

180. Ciche, T.A.; Darby, C.; Ehlers, R.U.; Forst, S.; Goodrich-Blaire, H. Dangerous liaisons: The symbiosis of entomopathogenic nematodes and bacteria. Biol. Control 2006, 38, 22-46. [CrossRef]

181. Givaudan, A.S.; Baghdiguian, S.; Lanois, A.; Boemare, N. Swarming and swimming changes concomitant with phase variation in Xenorhabdus nematophilus. Appl. Environ. Microbiol. 1995, 61, 1408-1413. [PubMed]

182. Volgyi, A.; Fodor, A.; Szentirmai, A.; Forst, S. Phase Variation in Xenorhabdus nematophilus. Appl. Environ. Microbiol. 1998, 64, 1188-1193. [PubMed]

183. Sugar, D.R.; Murfin, K.E.; Chaston, J.M.; Andersen, A.W.; Richards, G.R.; deLéon, L.; Baum, J.A.; Clinton, W.P.; Forst, S.; Goldman, B.S.; et al. Phenotypic variation and host interactions of Xenorhabdus bovienii SS-2004, the entomopathogenic symbiont of Steinernema jollieti nematodes. Environ. Microbiol. 2012, 14, 924-939. [CrossRef] [PubMed]

184. Akhurst, R.J.; Boemare, N.E. Biology and Taxonomy of Xenorhabdus. In Entomopathogenic Nematodes in Biological Control; Gaugler, R., Kaya, H.K., Eds.; CRC Press: Boca Raton, FL, USA, 1990; pp. 75-90.

185. Abdel-Razek, A.S. Pathogenicity of Bacteria Symbiotically Associated with Insect Pathogenic Nematodes against the Greater Wax Moth, Galleria mellonella. Arch. Phytopathol. Plant Prot. 2002, 35, 53-60. [CrossRef]

186. Herbert, E.E.; Goodrich-Blair, H. Friend and foe: The two faces of Xenorhabdus nematophila. Nat. Rev. Microbiol. 2007, 5, 634-646. [CrossRef] [PubMed]

187. Chattopadhyay, A.; Bhatnagar, N.B.; Bhatnagar, R. Bacterial Insecticidal Toxins. Crit. Rev. Microbiol. 2004, 30, 33-54. [CrossRef] [PubMed]

188. Dunphy, G.B.; Webster, J.M. Interaction of Xenorhabdus nematophilus subsp. Nematophilus with the hemolymph of Galleria mellonella. J. Insect Physiol. 1984, 30, 883-889. [CrossRef]

189. Dunphy, G.B.; Webster, J.M. Influence of the Mexican strain of Steinernema feltiae and its associated bacterium Xenorhabdus nematophilus on Galleria mellonella. J. Parasitol. 1986, 72, 130-135. [CrossRef]

190. Vallet-Gely, I.; Lemaitre, B.; Boccard, F. Bacterial strategies to overcome insect defences. Nat. Rev. Microbiol. 2008, 6, 302-313. [CrossRef] [PubMed]

191. Richards, G.R.; Goodrich-Blair, H. Masters of conquest and pillage: Xenorhabdus nematophila global regulators control transitions from virulence to nutrient acquisition. Cell. Microbiol. 2009, 11, 1025-1033. [CrossRef] [PubMed]

192. Khandelwal, P.; Banerjee-Bhatnagar, N. Insecticidal activity associated with the outer membrane vesicles of Xenorhabdus nematophilus. Appl. Environ. Microbiol. 2003, 69, 2032-2037. [CrossRef] [PubMed]

193. Herbert Tran, E.E.; Goodrich-Blair, H. CpxRA contributes to Xenorhabdus nematophila virulence through regulation of LRHA and modulation of insect immunity. Appl. Environ. Microbiol. 2009, 75, 3998-4006. [CrossRef] [PubMed] 
194. Ellis, T.N.; Kuehn, M.J. Virulence and immunomodulatory roles of bacterial outer membrane vesicles. Microbiol. Mol. Biol. Rev. 2010, 74, 81-94. [CrossRef] [PubMed]

195. McMullen, J.G.; Peterson, B.F.; Forst, S.; Blair, H.G.; Stock, S.P. Fitness costs of symbiont switching using entomopathogenic nematodes as a model. BMC Evol. Biol. 2017, 17, 100. [CrossRef] [PubMed]

196. McMullen, J.; McQuade, R.; Ogier, J.; Pagès, S.; Gaudriault, S.; Patricia Stock, S. Variable virulence phenotype of Xenorhabdus bovienii ( $\gamma$-Proteobacteria: Enterobacteriaceae) in the absence of their vector hosts. Microbiology 2017, 163, 510-522. [CrossRef] [PubMed]

197. McQuade, R.; Stock, S.P. Secretion Systems and Secreted Proteins in Gram-Negative Entomopathogenic Bacteria: Their Roles in Insect Virulence and Beyond. Insects 2018, 9, 68. [CrossRef] [PubMed]

198. Brillard, J.; Duchaud, E.; Boemare, N.; Kunst, F.; Givaudan, A. The PhlA hemolysin from the entomopathogenic bacterium Photorhabdus luminescens belongs to the two-partner secretion family of hemolysins. J. Bacteriol. 2002, 184, 3871-3878. [CrossRef] [PubMed]

199. Cowles, K.N.; Goodrich-Blair, H. Expression and activity of a Xenorhabdus nematophila haemolysin required for full virulence towards Manduca sexta insects. Cell. Microbiol. 2005, 7, 209-219. [CrossRef] [PubMed]

200. Murfin, K.E.; Whooley, A.C.; Klassen, J.L.; Goodrich-Blair, H. Comparison of Xenorhabdus bovienii bacterial strain genomes reveals diversity in symbiotic functions. BMC Genom. 2015, 16, 889. [CrossRef] [PubMed]

201. Chapuis, E.; Emelianoff, V.; Paulmier, V.; Le Brun, N.; Pages, S.; Sicard, M.; Ferdy, J.B. Manifold aspects of specificity in a nematode-bacterium mutualism. J. Evol. Biol. 2009, 22, 2104-2117. [CrossRef] [PubMed]

(C) 2018 by the authors. Licensee MDPI, Basel, Switzerland. This article is an open access article distributed under the terms and conditions of the Creative Commons Attribution (CC BY) license (http://creativecommons.org/licenses/by/4.0/). 